\title{
CONSEQUENCES OF OXIDATIVE STRESS IN AGE-RELATED MACULAR DEGENERATION
}

\author{
Stuart G. Jarrett ${ }^{1}$ and Michael E. Boulton ${ }^{2}$ \\ ${ }^{1}$ Department of Molecular and Biomedical Pharmacology, College of Medicine, University of \\ Kentucky, Lexington, KY \\ ${ }^{2}$ Department of Anatomy and Cell Biology, College of Medicine, University of Florida, Gainesville, \\ $\mathrm{FL}$
}

\begin{abstract}
Keywords
retina; age-related macular degeneration; oxidative stress; mitochondria; reactive oxygen species; antioxidants; cell regeneration
\end{abstract}

\section{Introduction}

The retina resides in an environment that is primed for the generation of reactive oxygen species (ROS) and resultant oxidative damage. The retina is one of the highest oxygenconsuming tissues in the human body (Yu and Cringle, 2005). The highest oxygen levels are found in the choroid, but this falls dramatically across the outermost retina, creating a large gradient of oxygen towards the retina and inner segments of the photoreceptors which contain high levels of polyunsaturated fatty acids. This micro-environment together with abundant photosensitizers, visible light exposure and a high energy demand supports a highly oxidative milieu. However, oxidative damage is normally minimized by the presence of a range of antioxidant and efficient repair systems. Unfortunately, as we age oxidative damage increases, antioxidant capacity decreases and the efficiency of reparative systems become impaired. The result is retinal dysfunction and cell loss leading to visual impairment. It appears that these age-related oxidative changes are a hallmark of early agerelated macular degeneration (AMD) which, in combination with hereditary susceptibility and other retinal modifiers, can progress to the pathology and visual morbidity associated with advanced AMD. This review reassesses the consequences of oxidative stress in AMD and strategies for preventing or reversing oxidative damage in retinal tissues.

\section{Generation of Reactive Oxygen/Nitrogen Species}

\subsection{Reactive oxygen and nitrogen species}

ROS and reactive nitrogen species (RNS) are highly reactive molecules acting in concert to modify proteins, nucleic acids, carbohydrates and lipids, often resulting in dysfunction of the biomolecule (Gutteridge and Halliwell, 2000) (also see reviews by Mettu and Sparrow in

(C) 2012 Elsevier Ltd. All rights reserved.

Address for correspondence: Michael E Boulton, PhD, Department of Anatomy and Cell Biology College of Medicine, University of Florida, PO Box 100235, Gainesville, FL 32610-0235, meboulton@ufl.edu.

Publisher's Disclaimer: This is a PDF file of an unedited manuscript that has been accepted for publication. As a service to our customers we are providing this early version of the manuscript. The manuscript will undergo copyediting, typesetting, and review of the resulting proof before it is published in its final citable form. Please note that during the production process errors may be discovered which could affect the content, and all legal disclaimers that apply to the journal pertain. 
this issue). ROS and RNS are terms that commonly define either a free radical (i.e. a species that contains one or more unpaired electrons in the outer molecular orbitals), powerful oxidizing agents (e.g. hydrogen peroxide $\left(\mathrm{H}_{2} \mathrm{O}_{2}\right)$ or peroxynitrite $\left(\mathrm{ONOO}^{-}\right)$) or a species that exists at a higher energy level (e.g. singlet oxygen; ${ }^{1} \mathrm{O}_{2}$ ). At a physiological level, ROS and RNS can function as signaling molecules in crucial regulatory pathways including cell proliferation, gene expression and apoptosis (Leonarduzzi et al., 2011). However, ROS/RNS levels above physiological, or an imbalance in the oxidant/antioxidant ratio, can have significant pathophysiological consequences (Gutteridge and Halliwell, 2000).

The cascade of oxygen radical production begins with a single electron reduction of molecular oxygen $\left(\mathrm{O}_{2}\right)$ to form superoxide anion $\left(\mathrm{O}_{2}{ }^{-}\right)$, which dismutates in the presence of either superoxide dismutase 1 or 2 (SOD1/2) into $\mathrm{H}_{2} \mathrm{O}_{2}$ and $\mathrm{O}_{2}{ }^{--}\left(2 \mathrm{O}_{2}{ }^{--}+2 \mathrm{H}^{+} \rightarrow \mathrm{H}_{2} \mathrm{O}_{2}+\right.$ $\mathrm{O}_{2}$ ). One of the most destructive ROS, the hydroxyl radical $\left(\mathrm{OH}^{*}\right)$, is formed through an iron-catalyzed Fenton reaction $\left(\mathrm{Fe}^{2+}+\mathrm{H}_{2} \mathrm{O}_{2} \rightarrow \mathrm{Fe}^{3+}+\mathrm{OH}^{-}+\mathrm{OH}^{-}\right)$. Although $\mathrm{O}_{2} \cdot-$ is orders of magnitude less reactive than $\mathrm{OH}^{\prime}$, its reaction with nitric oxide (NO) forms the highly reactive oxidizing agent, peroxynitrite $\left(\mathrm{NO}+\mathrm{O}_{2}{ }^{-} \rightarrow \mathrm{ONOO}^{-}\right)$. Lipid radicals $(\mathrm{L}$, $\mathrm{LO}^{\prime}$, and $\mathrm{LOO}^{\prime}$ ) are also generated via lipid peroxidation initiated by a ROS-induced hydrogen atom abstraction from a C-H bond of lipid. The half-lives of ROS/RNS vary from nanoseconds for the most reactive $\mathrm{ROS}$ (e.g. $\mathrm{OH}^{-}$) to minutes for rather stable oxidants (e.g. $\mathrm{H}_{2} \mathrm{O}_{2}$ ) (Winkler et al., 1999).

\subsection{Cellular Origins of ROS}

ROS can be derived from numerous intracellular sources such as mitochondria, enzyme systems or photosensitizers or occur as a result of exogenous influences (e.g. smoking, irradiation, diet).

2.2.1 Mitochondria-Mitochondria account for the majority of endogenously formed ROS in most cells of the retina (Gutteridge and Halliwell, 2000; Winkler et al., 1999). The mitochondrial respiratory chain generates substantial mitochondrial ROS (Beckman and Ames, 1998; Harman, 1972; Sastre et al., 2000), through electron leakage, chiefly from complexes I and III, resulting in the formation of $\mathrm{O}_{2}{ }^{--}$(Brand et al., 2004). The mitochondrial superoxide dismutase $\left(\mathrm{Mn}^{2+} \mathrm{SOD} ;\right.$ SOD2), converts $\mathrm{O}_{2}{ }^{-}{ }^{-}$into $\mathrm{H}_{2} \mathrm{O}_{2}$, however the highly reactive $\mathrm{OH}^{\prime}$ is also produced via Fenton chemistry. Proteins containing Fe-S catalytic sites are abundant in the mitochondria e.g. respiratory complexes I, II, III and aconitase. These are sensitive to $\mathrm{O}_{2}{ }^{-}$attack and subsequent inactivation (Fridovich, 1997; Patel et al., 1996), resulting in progressive $\mathrm{Fe}^{2+}$ accumulation and $\mathrm{H}_{2} \mathrm{O}_{2}$, the main ingredients of Fenton chemistry (Cantu et al., 2011). The close proximity of ROS and RNS generating systems (i.e. respiratory chain and nitric oxide synthase) results in the generation of ONOO-, a damaging oxidant capable of diffusing through the mitochondrial membrane into the cytoplasm (Beckman, 1996; Pacher et al., 2007). All mitochondrial localized ROS also have the potential to initiate peroxidation of mitochondrial membrane lipids (Esterbauer et al., 1991) and to generate mitochondrial DNA damage which in turn induces a "vicious cycle" of ROS generation (Jarrett et al., 2010).

2.2.2 NADPH oxidase-Reduced nicotinamide adenine dinucleotide phosphate (NADPH) oxidase is a membrane bound enzyme complex that catalyzes the formation of $\mathrm{O}_{2}{ }^{-}$from $\mathrm{O}_{2}$ and NADPH (NADPH $+2 \mathrm{O}_{2} \rightarrow \mathrm{NADP}^{+}+\mathrm{H}^{+}+2 \mathrm{O}_{2}{ }^{-}$). Classically, NADPH oxidases were thought of as enzymes found in neutrophils, eosinophils, monocytes and macropghages, with the sole purpose to kill organisms in contact with phagocytes (Bylund et al., 2010). However, it has now become apparent that the NADPH oxidase family of enzymes comprises at least seven members (i.e. NOXs 1-5, DUOX1, and DUOX2), generating $\mathrm{O}_{2}{ }^{--}$via their "Nox" catalytic subunit. Nox enzymes contribute to many 
biological and pathological processes, including blood pressure, inflammation, cell growth and differentiation. NADPH oxidase is of major importance in vascular endothelial cells where, in addition to its signaling role, it is considered to be a major source of ROS (Bedard and Krause, 2007; Paravicini and Touyz, 2008). Of interest, newly identified interactions between NADPH oxidase and mitochondria have been purported to result in a "vicious cycle" of ROS amplification promoting aging and disease states (Desouki et al., 2005). Phagocytosis of photoreceptor outer segments subjects RPE cells to an oxidative burst similar to that observed in macrophages (Miceli et al., 1994). The resultant intracellular $\mathrm{H}_{2} \mathrm{O}_{2}$ is thought to result from either or a combination of NADPH oxidase in the phagosome or beta-oxidation of outer segment lipids in peroxisomes.

2.2.3 Peroxisomes-Mammalian peroxisomes play a key role in various metabolic pathways, including fatty acid $\alpha$ - and $\beta$-oxidation, glyoxylate metabolism, amino acid catabolism, polyamine oxidation, and the pentose phosphate pathway (Ivashchenko et al., 2011). Interestingly, many of the enzymes participating in these pathways generate specific ROS as byproducts of their normal catalytic function. Most are flavine adenine dinucleotide (FAD) or flavine mononucleotide (FMN)-dependent oxidases that generate $\mathrm{H}_{2} \mathrm{O}_{2}$ (Antonenkov et al.). Peroxisomes also contain xanthine oxidoreductase and the inducible form of nitric oxide synthase which are further potential sources of $\mathrm{O}_{2}{ }^{--}$and $\mathrm{NO}$ respectively (Bonekamp et al., 2009).

2.2.4 Phospholipase $\mathbf{A}_{\mathbf{2}}$-The superfamily of phospholipase $\mathrm{A}_{2}\left(\mathrm{PLA}_{2}\right)$ are ubiquitous enzymes that maintain the integrity of cell membranes and produce lipid mediators that regulate cell functions (Tsimikas, 2008). Recent studies have linked PLA 2 activity to ROS production and lipid peroxidation. For example, $\mathrm{PLA}_{2}$-induced cleavage of membrane phospholipids results in the release of arachidonic acid, a substrate for ROS-generating enzyme systems such as the lipoxygenases (Braca et al., 2011). In addition, cross-talk appears to exist between pathways that regulate expression/activation of cytosolic $\mathrm{PLA}_{2}-$ and secreted PLA 2 -dependent inflammatory responses (Sun et al., 2010), possibly mediated by NADPH oxidase, thereby increasing cellular $\mathrm{O}_{2}{ }^{--}$load (Sun et al., 2007).

2.2.5 Light and endogenous photosensitizers-A photosensitizer is a lightabsorbing substance that initiates a photochemical or photophysical reaction. The retina contains a large number of chromophores many of which become photosensitizers when excited by the appropriate wavelength of light (reviewed in (Boulton et al., 2001)). After initial photon absorption, a change in distribution of electrons in the chromophores/ photosensitizer molecule occurs and generates an excited singlet state. In this long-lived state, interactions with other intracellular molecules occur generating ROS either via electron transfer (type I photosensitization), or singlet oxygen (type II photosensitization) (Kruft and Greer, 2011).

2.2.6 Exogenous factors that contribute to ROS generation-Exogenous sources of oxidative stress include alcohol consumption, tobacco usage (including passive smoking) and, exercise. Acute and/or chronic alcohol exposure enhances ROS levels, DNA, protein and lipid oxidation (Tsukamoto and $\mathrm{Lu}, 2001$ ). The oxidation of ethanol generates a variety of by-products and causes antioxidant depletion, of interest, ethanol acts as an $\mathrm{OH}^{\cdot}$ scavenger and readily generates 1-hydroxylethyl radical (HER), a species that has the potential to disrupt the cellular antioxidant/oxidant ratio (Reinke, 2002). Cigarette smoke is an exceptionally rich source of oxidants both in the gaseous and water-soluble phases (cigarette smoke contains $\sim 10^{15}$ radicals per inhalation and $\sim 10^{17}$ ESR-detectable radicals per gram of tar) (also see review by Handa in this issue). Significant sources of ROS are also present in the tar of cigarette combustion products and include $\mathrm{O}_{2}{ }^{--}$generating compounds 
e.g. quinine, hydroquinone, and semi-quinione (Pryor, 1992). In addition, tobacco leaf pyrolysis generates more than 2,000 aromatic compounds, semiquinones/quinones, iron, and oxides of nitrogen derived from nitrates (Cantin, 2010). Surprisingly, exercise can also be a source of oxidative stress (Jackson, 2005). It is assumed that during exercise, skeletal muscle is the predominant source of ROS, but, other tissues such as the heart, lungs, or blood may also significantly contribute. (Gomez-Cabrera et al., 2009).

\subsection{Oxidative Damage to DNA, Lipids, and Proteins}

2.3.1 Lipid peroxidation-The process of lipid peroxidation involves a complex chain reaction utilizing the interaction of oxygen-derived species with polyunsaturated fatty acids (e.g. docosahexaenoic acid, linoleic acid and arachidonic acid), resulting in highly reactive electrophilic aldehydes and free radicals (Esterbauer et al., 1991). This process is extremely detrimental to cellular functions as it disrupts membrane integrity, fluidity and function (Esterbauer et al., 1991). Lipid peroxidation is a self-propagating process involving initiation and propagation steps which continue through an ongoing free radical chain reaction until termination occurs. The predominant reactive aldehydes produced endogenously are 4-hydroxy-2-nonenal, malondialdehyde, acrolein, crotonaldehyde and methylglyoxal (reviewed in (Voulgaridou et al., 2011)), although other aldehyde products such as isoprostanes and free radicals (e.g. LO and LOO') are also formed (Comporti, 1998; Waldeck and Stocker, 1996). The retina is particularly prone to lipid peroxidation since it is highly enriched in polyunsaturated fatty acids (PUFAs) (Catala). The predominant PUFA in photoreceptor outer segments is docosahexanoic acid which is the most unsaturated fatty acid in the body.

2.3.2 Protein oxidation-Proteins are the largest constituent of the cellular milieu and are frequent targets of oxidative damage (Stadtman, 2006). Protein oxidation can involve direct reaction with amino acids, cleavage of the polypeptide chain, and conversion of the protein to derivatives that are highly sensitive to proteolytic degradation (see review by Shang, in this issue). It has also been established that all of these protein modifications can be mediated by metal-catalyzed oxidation systems. All amino acid residues of proteins are potential targets for oxidation by $\mathrm{HO}^{\prime}$ or by $\mathrm{H}_{2} \mathrm{O}_{2}$ in the presence of metal ions. For example, oxidation of tyrosine residues is damaging to the cell, as this amino acid is converted to a 3,4-dihydroxyphenylanine derivative, which itself can undergo redox cycling to generate further ROS (Sugiura and Ichinose, 2011). Another well-characterized amino acid modification is the irreversible addition of carbonyl groups that arise from direct oxidation of most amino acid residues. The reactive carbonyl compounds formed during lipid peroxidation (e.g. advanced lipid peroxidation end products) form adducts and crosslinks with proteins (e.g. Michael addition adducts (Stadtman and Levine, 2000)), which progressively lead to impaired protein function with pathological consequence (NegreSalvayre et al., 2008). The protein backbone is also susceptible to oxidation and usually involves the $\mathrm{HO}^{-}$-dependent abstraction of the alpha-hydrogen atom from an amino acid, generating a carbon-centered radical derivative that, in the presence of $\mathrm{O}_{2}$, generates ROS that have the capability to cause peptide bond and/or protein backbone cleavage (Stadtman, 2006).

2.3.3 DNA oxidation-Oxidative DNA damage to both the nuclear and mitochondrial genomes can result in strand breaks, base modifications and DNA-protein cross linkages, which are all strongly implicated in aging and age-related disease (Bohr et al., 1998; Bohr et al., 2007). There have been over 20 base modifications related to ROS attack of DNA identified, with the predominant oxidative DNA damage products being 8-oxo-7,8dihydroadenine, 8-oxo-7,8-dihydroguanine, 8-oxo-7,8-dihydro-2' ${ }^{\prime}$-deoxyguanosine (8oxodG), and 5,6-dihydroxy-5,6-dihydrothymine as well as the ring-opened lesions of 4,6- 
diamino-5-formamido-pyrimidine and 2,6-diamino-4-hydroxy-5-formamido-pyrimidine (Breen and Murphy, 1995). Of these oxidative lesions, 8-oxodG (which is formed through the oxidation of guanine at the $\mathrm{C} 8$ position in the guanine base) has received most attention due to its potential to serve as a reliable biomarker of oxidative stress and its association with aging and disease (Bohr et al., 2007). The most damaging ROS to DNA is $\mathrm{OH}$, which reacts with DNA by addition to double bonds of DNA bases with a rate constant of $\sim 10 \times$ $10^{9} \mathrm{M}^{-1} \mathrm{~s}^{-1}$ and by abstraction of an $\mathrm{H}$ atom from the methyl group of a thymine and each of the C-H bonds of $2^{\prime}$-deoxyribose with a rate constant of $\sim 2 \times 10^{9} \mathrm{M}^{-1} \mathrm{~s}^{-1}$. In addition, the resultant $\mathrm{C}$ or $\mathrm{N}$ centered radicals of the DNA bases and C-centered radicals of the sugar moiety can further generate a plethora of DNA damage products (Dizdaroglu et al., 2002; Halliwell and Dizdaroglu, 1992). If oxidative DNA damage is not correctly or efficiently repaired, it may result in cell death, mutation, replication errors, and genomic instability, all of which have been associated with aging and age-related disease (Bohr et al., 1998).

2.3.4 Mitochondrial DNA oxidation-Mitochondrial DNA (mtDNA) differs from its nuclear counterpart in several aspects, which together appear to result in the high vulnerability of mtDNA to oxidative damage (Ames and Shigenaga, 1992; Yang et al., 2008). The high transcription rate for mtDNA increases the probability of genomic instability including mutations and/or deletions. Unlike nuclear DNA (nDNA), mtDNA is not surrounded by histones that can act as a physical barrier against ROS, however, mtDNA may be protected by Tfam and other nucleoid proteins (Cameron et al., 2011; Xu et al., 2011). Since mtDNA does not have introns, genomic injury will impact coding regions for critical components of mitochondrial translational machinery or the electron transport chain. The location of the mtDNA genome in close proximity to the electron transport chain that leaks ROS and the presence of metals ions within the inner mitochondrial membrane that provide the potential Fenton chemistry and generation of $\mathrm{OH}^{-}$makes mtDNA particularly vulnerable to oxidative damage (Spencer et al., 2011; Wallace, 2009, 2010). A further risk to mtDNA integrity is that mechanisms for repair of mtDNA oxidative damage tend to be less efficient in comparison to repair of oxidative damage in nDNA (Yakes and Van Houten, 1997). It appears that the sole mitochondrial polymerase, DNA polymerase $\gamma$, is a major target for ROS attack, through its catalytic subunit which is responsible for gap filling activity during DNA repair (Graziewicz et al., 2002). The oxidative inactivation of DNA polymerase $\gamma$ has been implicated as a principal factor in generating mitochondrial oxidative stress due to the loss of efficient mtDNA repair and replication (Harrison et al., 2005).

2.3.5 RNA oxidation-Messenger RNA and ribosomal RNA are vulnerable to ROSassociated injury predominately involving damage to the bases and ribose moieties (Kong and Lin, 2010). The majority of RNA damage is caused by $\mathrm{OH}^{-}$, with most common oxidized RNA base adducts being 8-oxoguanosine, 8-hydroxyadenine, and 5-

hydroxycitosine (Kong et al., 2008).

\subsection{Cellular redox state}

The cellular redox state is defined as the balance between oxidation/reduction reactions and is determined by the reduction potentials and reducing capacities of intracellular redox pairs (Sohal and Orr, 2011). Reduced glutathione/oxidized glutathione (GSH/GSSG), NADPH/ $\mathrm{NADP}^{+}, \mathrm{NADH} / \mathrm{NAD}^{+}$, thioredoxin (reduced)/thioredoxin (oxidized), glutaredoxin (reduced)/glutaredoxin (oxidized) are the major redox pairs. The GSH/GSSG ratio is 2-4 orders of magnitude higher than for any other redox pairs (Schafer and Buettner, 2001; Sohal and Orr, 2011). The oxidation/reduction reactions of cysteinyl thiols comprise a fundamental mechanism that controls and protects the activities of a wide array of proteins involved in cell metabolism, signaling, gene regulation, proliferation, apoptosis and DNA repair (Blank et al., 2010; Jahngen-Hodge et al., 1997; Obin et al., 1998). 


\subsection{Oxidative stress and aging}

Over the years numerous hypotheses have been put forward to explain the association between oxidative stress and age-related dysfunction at the cellular and whole organism level. The origins of the "Oxidative Stress Theory of Aging" date back to the 1890's when Fenton discovered that $\mathrm{Fe}^{2+}$, in the presence of $\mathrm{H}_{2} \mathrm{O}_{2}$, catalyzed oxidation reactions (Wardman and Candeias, 1996). Later it was proposed that $\mathrm{OH}, \mathrm{H}_{2} \mathrm{O}_{2}$, and $\mathrm{O}_{2}{ }^{-}$undergo a chain reaction that results in a net conversion of hydrogen peroxide into water. This is now known as the Haber-Weiss reaction and is at the center of metabolic cascades that generate most ROS in the cell (Koppenol, 2001; Liochev and Fridovich, 2002). Furthermore, the discovery of the damaging nature of oxidants in vivo and the identification of cellular antioxidants (e.g. SOD1 and SOD2) (McCord and Fridovich, 1969a, b), whose primary function are to prevent oxidative damage, strongly implicated an evolutionary benefit for cells to protect themselves from oxidative reactions.

The "Free Radical Hypothesis of Aging" was put forward 60 years ago. It proposes that endogenously produced oxygen free radicals are associated with the age-related stochastic accumulation of cellular damage. It has remained to this day a fundamental mechanism of aging and an explanation for the age-related decline in physiological fitness (Harman, 1956). Over the past two decades, it has become apparent that not just free radicals, but many other reactive species, such as peroxides, also play a role in oxidative damage to cells. Therefore, the "Free Radical Theory of Aging" was revised to a theory known as the "Oxidative Stress Hypothesis". In addition, much recent research has implicated the mitochondria as the main source of ROS generation in most cell types, thereby the "Mitochondria Hypothesis of Aging" has also been put forward and gained much support (Ames, 2010; Harman, 1972; Liu et al., 2002; Sanz and Stefanatos, 2008). However, over the past decade there has been a shift in the perception of ROS in cellular physiology, for instance, some oxidants (e.g. $\mathrm{H}_{2} \mathrm{O}_{2}$ ) are vital for cellular survival by allowing routine cell signaling, gene regulation, and cellular differentiation to take place via controlling the cellular redox state, or the balance between oxidation/reduction reactions (Blank et al., 2010). In recent years, several labs have suggested that the oxidative stress theory should be modified to include a shift in cellular redox state. Dubbed the "redox stress hypothesis" (Blank et al., 2010; Jones, 2006; Schafer and Buettner, 2001; Sohal and Orr, 2011), it proposes that "aging associated functional losses are primarily caused by a progressive pro-oxidizing shift in the redox state of cells, which leads to the over-oxidation of redox-sensitive protein thiols and the consequent disruption of the redox-regulated signaling pathways" (Sohal and Orr, 2011). It is important to emphasize that the common theme to these theories is that the rate of aging is a function of an imbalance between ROS and antioxidant defenses resulting in the accrual of structural damage. Furthermore, it is clear that oxidative stress is an underlying factor in numerous age-related neurodegenerative diseases including Alzheimer's disease, Parkinson's disease and AMD (Beatty et al., 2000; Jarrett et al., 2010; Jomova et al., 2010; Romano et al., 2010). In all these conditions, protein side-chains and DNA are modified either directly by ROS or RNS, or indirectly, by the products of lipid peroxidation (Jomova et al., 2010).

\section{Cellular Strategies for Protecting Against Oxidative Damage}

Cells have developed three major strategies to prevent or minimize oxidative damage; antioxidants, molecular repair and cellular replacement.

\subsection{Antioxidants}

Antioxidant systems have evolved to protect biological systems against the deleterious effects of a wide array of ROS. Antioxidants can be broadly divided into enzymic and nonenzymic. The major enzymic antioxidants are superoxide dismutase, catalase and 
glutathione peroxidase (Halliwell and Gutteridge, 1999). Superoxide dismutase exists as a copper, zinc-enzyme (SOD1) that is found in the cytoplasm or a manganese containing enzyme that is located in mitochondria (SOD2). These enzymes catalyze the one-electron dismutation of $\mathrm{O}_{2}^{--}\left(2 \mathrm{O}_{2}^{--}+2 \mathrm{H}^{+} \rightarrow \mathrm{H}_{2} \mathrm{O}_{2}+\mathrm{O}_{2}\right)$. Catalase is an iron-dependent enzyme that directly scavenges $\mathrm{H}_{2} \mathrm{O}_{2}\left(2 \mathrm{H}_{2} \mathrm{O}_{2} \rightarrow 2 \mathrm{H}_{2} \mathrm{O}+\mathrm{O}_{2}\right)$. Furthermore, glutathione peroxidases (GPXs) are a family of enzymes that reduce a variety of organic and inorganic hydroperoxides to the corresponding hydroxyl derivatives in the presence of glutathione (GSH). In this process, GSH is converted to an oxidized disulfide $\left(2 \mathrm{GSH}+\mathrm{H}_{2} \mathrm{O}_{2} \rightarrow\right.$ GS-SG $+2 \mathrm{H}_{2} \mathrm{O}$ ). GSH is the major soluble antioxidant in the cell and is present at high concentrations in the cytosol $(1-11 \mathrm{mM})$, nuclei $(3-15 \mathrm{mM})$ and mitochondria $(5-11 \mathrm{mM})$, and is further capable of reducing peroxides via its antioxidant thiol group. Protection against ROS is also supplied by non enzymatic, dietary antioxidants which cannot be synthesized endogenously by humans. These molecules include tocopherol homologues, carotenoids, ascorbate, flavonoids and many more. a-tocopherol is a lipid soluble scavenger able to inhibit lipid peroxidation in cell membranes. Carotenoids are distributed throughout the body but lutein, zeaxanthin and mesozeazanthin are the predominant carotenoids in the retina where they are often referred to as macular pigment (Beatty et al., 2000; Boulton et al., 2001). Carotenoids are potent scavengers of a variety of ROS including singlet oxygen (Boulton et al., 2001). Ascorbate has a low reduction potential allowing it to act as a reducing agent against $\mathrm{OH}, \mathrm{O}_{2}^{--}$and peroxyl radicals. Like GSH, it is also present at $\mathrm{mM}$ concentrations (Taylor et al., 1995). Additional protection in the eye can be derived from melanin, which although a weak antioxidant, binds cations such as $\mathrm{Fe}^{2+}$ and thus minimizes their potential for entering the Fenton reaction (Sarna, 1992).

\subsection{Molecular repair (removal and replacement)}

Despite effective and multiple antioxidant systems, a small proportion of ROS will escape and cause oxidative modifications of cellular components. However, cells have evolved systems to negate the functional impact by removing or repairing oxidatively modified biomolecules (See review by Shang in this issue). Lysosomal and proteasomal systems with assistance from autophagic and endosomal pathways can degrade oxidised proteins (Davies, 2001; Szweda et al., 2003). Phospholipase and peroxisomes can remove lipid peroxidation products although these can be repaired by hydroperoxide glutathione peroxidase or phospholipase $\mathrm{A}_{2}$ (Halliwell and Gutteridge, 1999). Cells have also developed a vast array of DNA repair pathways of which the base excision repair (BER) pathway is probably the most important for repairing oxidative base lesions in DNA (Dianov et al., 2001). Although BER functions efficiently for nuclear DNA its ability to repair oxidative damage to mtDNA is less effective and mtDNA damage repairs poorly (Liang and Godley, 2003). It is this inability of mtDNA to repair oxidative damage effectively that is thought make a major contribution to cell aging (Jarrett et al., 2010).

Cells can adapt to oxidative stress by a biological phenomenon in which cells acquire greater cellular resistance against a wide range of physiological stresses, including ROS (Crawford and Davies, 1994). For example, exposure of cultured retinal pigment epithelial (RPE) cells to sublethal oxidative stress results in a greater cellular resistance to subsequent oxidative stress compared to non-adapted RPE (Jarrett and Boulton, 2005) This adaptive response is often associated with a sustained increase in antioxidant capacity.

\subsection{Cellular replacement}

Even with the best biological antioxidant defenses and repair systems there will always be some chronic oxidative damage which will accumulate throughout life eventually resulting in cellular dysfunction and/or cell death. In order to maintain optimal tissue and organ function dead and dysfunctional cells need to be replaced, usually from stem or progenitor 
cell populations (Lamba et al., 2009b). Without introduction of exogenous cells, this is not usually possible for RPE.

\section{AMD and oxidative stress}

\subsection{What is AMD}

It is not our intention to provide an in depth description of the clinical and pathological features of AMD as this has been covered in detail by others (Beatty et al., 2000; Khandhadia and Lotery, 2010; Zarbin, 2004) or can be found in ophthalmology text books (see reviews by Bhutto and Mettu in this issue). A figure is provided for the reader to familiarize themselves with the anatomy of the eye and retina (Fig 1). AMD is the major cause of blindness in the elderly with over 1.7 million people having reduced vision due to AMD in the US (Friedman et al., 2004). The disease affects the macula at the center of the eye and as a consequence results in loss of central vision which significantly impacts the patient's ability to read, watch television or drive. This disorder appears to consist of both a genetic and environmental component with a number of gene polymorphisms being identified which increase susceptibility to environmental risk factors such as smoking, hypertension, diet, oxidative stress (reviewed in (Ding et al., 2009; Khandhadia and Lotery, 2010; Montezuma et al., 2007; Swaroop et al., 2009; Ting et al., 2009) and see review by Gorin in this issue). Early AMD is characterized by any of the following findings in the macular area: soft Drusen (sub RPE deposits), choroidal or outer retinal hyperpigmentation associated with Drusen and depigmentation of the RPE (Beatty et al., 2000). AMD is broadly divided into two forms: dry and wet that account for about $85 \%$ and $15 \%$ of cases respectively. Wet AMD, the most severe form of AMD, is generally associated with subretinal (i.e. between the retina and choroid) neovascularization and considerable amelioration can be achieved with the use of antiangiogenic agents (e.g. Lucentis and Avastin) (Andreoli and Miller, 2007). By contrast, dry AMD, often referred to as atrophic or non-exudative, exhibits slow progression of disease. Dry AMD presents as areas of hyperand hypo-pigmentation of the RPE, elevated retinal autofluorescence due to lipofuscin formation, the formation of Drusen and RPE cell death (de Jong, 2006; Zarbin, 2004). RPE cell loss appears as regions of geographic atrophy within the retinal arcades that slowly increase in size and will eventually impinge on the macula. The death of RPE cells results in degeneration of the overlying photoreceptors and atrophy of the underlying choroidal capillaries (de Jong, 2006; Zarbin, 2004). Unfortunately, unlike wet AMD, there is currently no proven treatment for dry AMD, but regeneration or replacement therapy of the RPE monolayer offers a potential cell-based therapy.

\subsection{The evidence for an association between oxidative stress and AMD}

Age-related changes in the retina have been well documented and are typified by cell loss, lipofuscin accumulation, Bruch's membrane changes and Drusen, all of which begin to impact on retinal function after the age of 50-60 years. With increasing age antioxidant levels decline and ROS levels increase in most tissues and this is associated with a number of neurodegenerative diseases (Halliwell and Gutteridge, 1999). Even though the neural retina and RPE are rich in both enzymatic and non-enzymic antioxidants (Beatty et al., 2000; Winkler et al., 1999; Zarbin, 2004), ROS levels increase and the ensuing oxidative damage shows a positive association with retinal aging (Beatty et al., 2000; de Jong, 2006; Khandhadia and Lotery, 2010; Zarbin, 2004). Despite extensive research the age-related changes in antioxidants remain equivocal. For example, Miyamura and colleagues did not report age-related changes in either catalase or heme oxygenase (HO)-1 in the RPE (Miyamura et al., 2004) while others have reported that catalase activity, but not superoxide dismutase, decreases with age in the human RPE (Liles et al., 1991). However, there is an age-related association with decreased levels of macular carotenoids (Beatty et al., 2001), a 
greater than 3 fold decrease in microsomal glutathione S-transferase-1 (an enzyme that reduces peroxides, oxidized RPE lipids and oxidized retinoids) (Maeda et al., 2005), reduced Vitamin E levels after the 7th decade in the human macular (Friedrichson et al., 1995) and increased lipid peroxidation (Castorina et al., 1992). Truncation of the chaperone aBcrystallin can reduce its ability to protect proteins from oxidative damage (Liao et al., 2002; Organisciak et al., 2006). It is interesting to note that antioxidant activity, especially in the RPE shows considerable cell to cell variation (Miyamura et al., 2004). In support of oxidative damage to the retina studies have shown an age related increase in a) lipofuscin, a potent photoinducible generator of ROS, in the RPE (Boulton et al., 2001), b) 8-oxodG in the retina (Wang et al., 2008), c) mtDNA damage (Jarrett et al., 2010), d) carboxyethylpyrrole protein adducts (Crabb et al., 2002; Gu et al., 2003) e) advanced lipid peroxidation and glycation end products (Glenn and Stitt, 2009) and f) 4HNE and MDA (Castorina et al., 1992; Kopitz et al., 2004). These studies are backed up by a plethora of cell culture studies and animal models. However, it is difficult to assess whether a) age-related oxidative damage is primarily due to reduced antioxidant levels, increased ROS, or a combination of these or b) whether AMD is simply a manifestation of excessive aging or represents a distinct pathology independent of the general aging process. However, polymorphisms in antioxidant enzyme genes (Khandhadia and Lotery, 2010; Kimura et al., 2000), smoking as a risk factor and a plethora of in vitro studies support a role for oxidative stress in AMD. Furthermore, mouse models strongly support a role for oxidative stress in the development of AMD. Mice deficient in SOD1 or SOD2 (antioxidants that remove $\mathrm{O}_{2}^{\cdot{ }^{-}}$) suffer elevated levels of ROS and develop an AMD-like phenotype (Imamura et al., 2006; Justilien et al., 2007). A new animal model for AMD has recently been reported in which disruption of the nuclear factor erythroid 2-related factor 2 (Nrf2) gene increases the susceptibility of outer retina to pathology. Nrf2 is a transcription factor that plays a central role in the regulation of oxidative stress and induces the expression of several antioxidant enzymes. Nrf2-deficient mice developed retinal pathology that has similarities with human AMD including deregulated autophagy, oxidative injury and inflammation (Zhao et al., 2011). Unequivocal proof of oxidative stress as a major causative factor in AMD, however, is difficult due to the complex nature of AMD and its restriction, in the true form of the disease, to humans (Beatty et al., 2000; Winkler et al., 1999; Zarbin, 2004).

\section{Sources and Consequences and of ROS in the Retina}

There are numerous sources of ROS in the retina (Table 1). However, the level of oxidative damage will depend upon the efficiency of the antioxidant system. Lifelong accumulation of chronic oxidative damage will lead to dysfunction in retinal cells and increase their susceptibility to exogenous and endogenous insults eventually culminating in loss of visual function and cell death (Fig 2).

\subsection{Mitochondria}

As discussed earlier there is considerable evidence to support oxidative stress as a contributing factor in the onset and progression of AMD, with mitochondria representing a major source of endogenous reactive oxygen species (ROS) in the photoreceptors and underlying RPE (Jarrett et al., 2008; Liang and Godley, 2003). Numerous laboratories have provided direct evidence of mitochondrial dysfunction in AMD from both human tissues and animal models. Of particular interest, mtDNA appears to be particularly susceptible to oxidative stress-associated damage e.g. ROS-induced mutations and deletions (Karunadharma et al., 2010; Kenney et al., 2010; Wang et al., 2008). In fact, ROSassociated mtDNA damage is positively correlated with progression of AMD, while repair capacity is negatively correlated (Lin et al., 2011b). Defective oxidative stress-related DNA repair is also observed in AMD donor tissue, with higher basal endogenous DNA damage and less efficient repair of $\mathrm{H}_{2} \mathrm{O}_{2}$ and UV-induced DNA damage (Szaflik et al., 2009). Of 
note, the expression level of OGG1 (the major repair enzyme against oxidative DNA lesions) decreases by almost half in AMD macular RPE cells compared to aged macular RPE cells, suggesting that reduced levels of this protein in AMD (Lin et al., 2011b). Furthermore, a genetic component of mitochondrial stress appears to be in play as pigmentary abnormalities and RPE atrophy similar to those present in early AMD are detected in $75 \%$ of individuals with the A3243G MELAS mitochondrial DNA mutation (Jones et al., 2004). Intriguingly, certain mtDNA haplogroups have been reported to be associated with either increased or decreased prevalence of age-related maculopathy (Jones et al., 2007). In fact, a strong association between a variant of the protein ARMS2 and AMD has been reported and it has been proposed that ARMS2 is associated with mitochondria. (Kanda et al., 2007; Kanda et al., 2010). However, the function of ARMS2 remains unknown.

The majority of the mitochondrial dysfunction and oxidative stress studies in vitro have concentrated on the RPE even though mitochondria are prominent in photoreceptor inner segments. RPE cells survive higher levels of oxidative stress than many other cell types by a) elevating cellular antioxidants and b) having a higher nDNA repair capacity (Jarrett et al., 2006a). Human RPE cells exposed to oxidizing agents exhibit damage to mtDNA and this in turn leads to increased ROS generation (Godley et al., 2002; Jarrett and Boulton, 2005, 2007) Unfortunately, unlike nDNA repair, mtDNA repair in the RPE appears to be relatively slow and inefficient (Liang and Godley, 2003). The preferential susceptibility of mitochondria to oxidative damage and their poor repair capacity suggests that mitochondria are a weak link in the RPE cell's defenses against oxidative damage (Jarrett and Boulton, 2005). Mitochondrial oxidative stress is further enhanced by phagocytosis of photoreceptor outer segments, presumably through the burst of ROS generated during ingestion, and by exposure to blue light (Godley et al., 2005; Jin et al., 2001). Animal models of mitochondrial oxidative stress, involving knockdown of SOD2, have confirmed pathological lesions similar to those observed in "dry" AMD (Justilien et al., 2007) and over-expression of SOD2 protects against oxygen-induced apoptosis in mouse RPE and retinal cells (Kanwar et al., 2007; Kasahara et al., 2005). These findings strongly support that mitochondrial oxidative stress is a feature of aging and may be a pivotal factor that by reducing cell function, underlies the development of AMD.

\subsection{NADPH oxidase}

The active NADPH oxidase complex consists of two membrane-bound catalytic subunits, p22phox and gp91phox, and cytoplasmic proteins p40phox, p47phox, and p67phox that generate $\mathrm{O}_{2}{ }^{-}$- (Segal and Abo, 1993). Recent studies show that pro-inflammatory cytokines, tumor necrosis factor- $a$, interleukin- $1 b$, and interferon-, induce ROS in RPE cells via mitochondria and NADPH oxidase (Yang et al., 2007). The cross talk between NADPH oxidases and mitochondria may represent a "vicious cycle" of ROS production with mitochondria being a target for NADPH oxidase-generated ROS and mitochondrial ROS under certain conditions may stimulate NADPH oxidases. An example of cross-talk between mitochondria and NADPH oxidase has been recently shown with SOD2 depletion causing an increase in NADPH oxidase activity, whereas SOD2 over-expression reduces activation of NADPH oxidases and NADPH-generated ROS (Dikalova et al., 2010). Elevated NADPH oxidase shows a strong association with endothelial dysfunction and angiogenesis (Bedard and Krause, 2007; Ushio-Fukai and Alexander, 2004). In the retina, increased NADPH oxidase activity can a) promote angiogenesis (Al-Shabrawey et al., 2005; Hartnett, 2010), b) increase leucocyte adhesion and vascular leakage (Tawfik et al., 2009) and c) result in AGE accumulation (Li and Renier, 2006). In contrast, inhibition of NADPH oxidase activity can reduce background retinopathy and inhibit preretinal angiogenesis (Al-Shabrawey et al., 2008; Hartnett, 2010; Tawfik et al., 2009), inhibit choroidal neovascularization (Li et al., 
2008) and block VEGF overexpression (Al-Shabrawey et al., 2005). Down-regulation of the RPE-localized p22phox subunit in vivo efficiently inhibits the development of choroidal neovascularization in a mouse model suggesting that NADPH oxidase-derived ROS may play an important role in promoting the pathogenesis of AMD (Li et al., 2008).

\subsection{Light and photosensitizers}

Although light and oxygen are essential for vision they can also lead to the photogeneration of ROS and subsequent photochemical damage to the retina. The retina contains a variety of chromophores which when excited at the appropriate wavelength can lead to significant photochemical damage (Boulton et al., 2001). The two major photosensitizers in the retina are the visual pigments in photoreceptor cells and lipofuscin which accumulates with age in the RPE (Boulton et al., 2001). Other photoreactive molecules in the retina that can photogenerate ROS under certain conditions include melanin, hemoglobin and other iron containing proteins (e.g. cytochrome C), flavins, flavoproteins and carotenoids (Boulton et al., 2001). Photochemical damage in the retina can be broadly divided into two categories. Ham type damage, often referred to as blue light damage, is caused by relatively high irradiances and short exposures (seconds to minutes) and is considered to originate in the RPE (Ham et al., 1984). It was originally thought the melanin was the primary photosensitizer but this does not match the action spectra and subsequent studies indicate that lipofuscin and cytochromes make a significant contribution (Boulton et al., 2001). Noell type damage is caused by low irradiances and longer exposures (typically hours or even days) and damage of this type is first observed in phororeceptors (Noell et al., 1966) and corresponds to the absorption spectrum of the visual pigments (Boulton et al., 2001; Mellerio, 1994; Noell and Albrecht, 1971; Organisciak and Noell, 1977). However, it appears that it is vitamin A metabolites rather than rhodopsin itself, that are the photosensitisers responsible for retinal photodamage. For example, all-trans retinal (vitamin A aldehyde), which is a product of photobleaching of rhodopsin, is highly photoreactive when exposed to blue light. Retinal exposed to blue light undergoes intersystem crossing and forms a triplet state and singlet oxygen is produced (Bensasson et al., 1993). As expected retinol (vitamin A) deficiency protects against light damage to the retina and this is probably due to the reduced availability of photoreactive vitamin A metabolites (Grimm et al., 2001).

The age-related accumulation of the age pigment lipofuscin within the RPE is strongly associated with AMD (Boulton, 2009). We and others have demonstrated that lipofuscin is a potent photoinducible generator of a range of ROS including superoxide anion, singlet oxygen, hydrogen peroxide and lipid peroxides (Gaillard et al., 1995; Rozanowska et al., 1995; Rozanowska et al., 1998). ROS production is strongly dependent on the visible wavelength of light since highest levels of ROS were generated when lipofuscin was exposed to blue light compared to longer wavelengths. Furthermore, the photogeneration of ROS by individual lipofuscin granules increases with age (Rozanowska et al., 2004). Exposure of cultured RPE cells containing lipofuscin to blue light resulted in lipofuscindependent protein oxidation, lipid peroxidation, mitochondrial DNA damage, lysosmal changes and cell death (Davies et al., 2001; Godley et al., 2005; Shamsi and Boulton, 2001). The most studied of the potential photosensitizer molecules in lipofuscin is the bisretinoid, A2E which when exposed to blue light can induce RPE cell death (Sparrow and Boulton, 2005) (see review by Sparrow in this issue). However, given that the photoreactivity of A2E is at least an order of magnitude less than RPE lipofuscin granules containing equivalent A2E concentrations suggests the presence of other more reactive chromophores which may or may not be of retinoid origin (Pawlak et al., 2003; Rozanowska and Sarna, 2005).

Flavins and porphyrins may be the chromophores responsible for blue light-induced mitochondrial damage (Boulton et al., 2001; Godley et al., 2005). The macular carotenoids 
lutein and zeaxanthin have the potential for prooxidant properties under certain conditions (Lowe et al., 2003) even though they are widely regarded as being effective antioxidants in the eye. Following interaction of carotenoids with ROS, the carotenoid molecule is itself oxidized to generate a radical and the formation of a carotenoid peroxyl radical can initiate further lipoperoxidation. Furthermore, carotenoid breakdown products have been shown to be toxic to RPE cells (Kalariya et al., 2009). Although melanosomes are considered to be protective in the RPE it has been reported that blue light photoreactivity of melanosomes increases with age and this can result in RPE cell death (Rozanowska et al., 2002;

Rozanowski et al., 2008).

\subsection{Smoking}

Cigarette smoking has been consistently identified as a strong risk factor in AMD and this appears to be both gender and AMD type-dependent (Ni Dhubhghaill et al., 2010; Thornton et al., 2005) (see review by Handa in this issue). While smokers have up to a 6.6 fold risk of developing wet AMD (Thornton et al., 2005; Vingerling et al., 1996) the exact contribution to dry AMD remains unclear. Cigarette smoke can increase oxidative stress through either the generation of ROS or a reduction in antioxidant capacity (Espinosa-Heidmann et al., 2006; Seddon et al., 2006). It is well recognized that the levels of plasma lipid peroxidation, including free malondialdehyde and thiobarbitunic acid-reactive substances, is significantly higher in smoker compared to non smokers and these can be reduced by cessation of smoking (Altuntas et al., 2002; Bamonti et al., 2006; Kim et al., 2003; Polidori et al., 2003; Traber et al., 2001). In addition, serum carotenoids, vitamin C, selenium, vitamin $\mathrm{E}$ and zinc are decreased in smokers (Gabriel et al., 2006; Galan et al., 2005; Kim et al., 2003; Traber et al., 2001). Cigarette smoking also correlates with the expression of proinflammatory cytokines such as c-reactive protein, prostaglandin F2a, interleukin 6 and FZ-isoprostane (Helmersson et al., 2005; Murphy et al., 2004; Seddon et al., 2006). C-reactive protein is associated with AMD and lower levels of serum C-reactive protein correlate with higher levels of serum antioxidants (Seddon et al., 2006). There also appears to be an association between smoking and susceptibility genes for AMD. For example, recent studies have shown that polymorphisms in complement Factor $\mathrm{H}$ are associated with over 50\% of AMD patients and it is proposed that a genetic susceptibility, for instance a variant of the complement Factor $\mathrm{H}$ gene ( $\mathrm{Y} 4 \mathrm{O} 2 \mathrm{H})$, coupled with a modifiable lifestyle factor such as cigarette smoking will confer a significantly higher risk of AMD than either factor alone (Delcourt et al., 2011; Seddon et al., 2006).

\subsection{Genetic polymorphisms}

The role of heredity in AMD has been supported by a number of epidemiologic studies that have found positive associations between having AMD and also having one or more affected family members (Seddon et al., 1997) (see review by Gorin in this issue). Of particular interest to this review, studies have now begun to provide evidence supporting a role for polymorphic genes associated with oxidative stress at various stages of AMD. A genetic role of SOD2 polymorphisms in the development of AMD, i.e. valine/alanine polymorphism is much more frequent in AMD patients than in healthy subjects (Kimura et al., 2000; Kowalski et al., 2010), with the lowest SOD2 expression noted in AMD patients (Kowalski et al., 2010). However, no association was found for SNPs within SOD2 in exon 2, intron 1 and in the $3^{\prime}$ UTR (Esfandiary et al., 2005). Further support for an important role for SOD comes from mouse models in which knockdown of either SOD1 $\left(\mathrm{Cu}^{++} \mathrm{Zn}^{++} \mathrm{SOD}\right)$ or SOD2 results in an AMD-like phenotype (Imamura et al., 2006; Justilien et al., 2007). Furthermore, the frequencies of a combination of glutathione S-transferase polymorphisms (M1, T1 and P1) may be a genetic risk factor for the development of wet AMD (Guven et al., 2011; Oz et al., 2006). In addition, a case-control study has determined that the frequency of 
polymorphisms in the DNA repair gene xeroderma pigmentosum complementation group D (XPD) at codon 751 is associated with the development of AMD (Gorgun et al., 2010).

\subsection{MicroRNAs}

MicroRNAs (miRNAs) are emerging classes of highly conserved, non-coding small RNAs that regulate gene expression on the post-transcriptional level by suppressing the translation of protein from mRNA or by enhancing mRNA degradation. Recent studies have implicated important roles for specific miRNAs in AMD. The dysregulation of ten microRNAs (upregulated: miR-106a, -146, -181, -199a, -214, -424, and -451; downregulated: miR-31, -150 , and -184) have been identified in an ischemia-induced retinal neovascularization model (Shen et al., 2008). The miRNA, mir-23 is associated with increased RPE cellular resistance to oxidative stress and was found to be significantly downregulated in macular RPE isolated from AMD patients (Lin et al., 2011a). In addition, reduced expression of mir-23 is strongly associated with pathological angiogenesis and angiogeneic signaling (Zhou et al., 2011). However, since miRNAs tend to target multiple genes their role in pathology and efficacy as therapeutic targets are as yet uncertain.

\section{Preventing or Reversing Oxidative Damage in the Retina}

To date the principal focus on alleviating oxidative stress in AMD has concentrated on the use of oral antioxidant combinations. However, success has been limited and there is now considerable interest in using cell regeneration therapy to treat late stage retinal degeneration. In addition, a number of other approaches are now being developed that can minimize oxidative damage or promote molecular repair.

\subsection{Antioxidants}

The multi-factorial role of oxidative stress in retinal aging and the pathology of AMD has made treatment approaches complex. However, targeting pathways that reduce oxidative damage and ROS generation offer valuable therapeutic strategies (see review by Weikel in this issue). Studies using dietary antioxidants must take into account a number of important factors; the synergistic relationship between different antioxidants, antioxidant concentrations, nutritional status of the patient cohort, the ability of the antioxidants to reach the cellular compartments responsible for ROS generation. However, the positive outcome of the original AREDS study has increased interest in alternative antioxidant therapies either from natural products or medicinal chemistry. The former include a product of green tea (epigallocatechin), Bilberry extract, curcumin, Ginkgo biloba extract, melon-derived SOD, resveratrol and quercetin (Khandhadia and Lotery, 2010). It should be emphasized that many antioxidants can also behave as prooxidants at high concentrations so intake should be kept within safe limits.

Recent clinical and in vitro data suggest that supplementation with zeaxanthin, the primary carotenoid in the retina (Stahl and Sies, 2005), may act as a beneficial antioxidant in treating disorders of the retina. Indeed, Zeaxanthin treatment in rats decreases retinal oxidative stress and oxidative damage to DNA (Kowluru and Kanwar, 2007). It has previously been shown that endogenous antioxidants such as melatonin, glutathione-S-transferase, ascorbic acid, $\mathrm{N}$ tert-butyl hydroxylamine, SOD2 up-regulation, and and $L$-carnitine have the capacity to protect against in vitro oxidative stress in the RPE, and possibly in vivo (Feher et al., 2003; Jarrett et al., 2006b; Kasahara et al., 2005; Liang et al., 2005; Liang et al., 2004; Reddy et al., 2004; Voloboueva et al., 2007). More recently two new antioxidant compounds have entered clinical trials, OT-551 and AL-8309. OT-551 (1-hydroxy-4cyclopropanecarbonyloxy-2,2,6,6-tetramethylpiperidine hydrochloride) is able to provide RPE cell protection against acute light damage (Tanito et al., 2010) and has been shown to 
be well tolerated in a phase II trial in patients with advanced geographic atrophy and may effect in maintaining visual acuity (Wong et al., 2010). AL-8309 is a serotonin (5hydroxytryptamine 1A) agonist which has been shown to protect against retinal light damage in rodents and to inhibit complement deposition and microglial activation (Collier et al., 2011a; Collier et al., 2011b). AL-8309 is now under evaluation in the clinic.

An alternative approach is to target the source of the ROS. An exciting and potentially revolutionary approach to AMD treatment is to use agents which specifically target the mitochondria. Mitotropic agents include delocalized lipophilic cations (DLCs) such as MitoQ (a triphenyl-phosphonium cation $\left(\mathrm{TPP}^{+}\right)$-linked derivative) (Chaturvedi and Beal, 2008; Cortes-Rojo and Rodriguez-Orozco, 2011). These act as back bones that carry a variety of antioxidants which are targeted to the inner membrane of mitochondria. Examples that have been shown to protect animal models against neurodegenerative disease include MitoPBN (phenyl tert-butylnitrone). Of special relevance to AMD, a mitochondrial-targeted MitoQ antioxidant protects RPE cells from blue light-induced oxidative stress (King et al., 2004). Recently, SkQ1 (plastoquinonyl-decyl-triphenylphosphonium) a mitochondriatargeted antioxidant has been shown to regress retinal damage in a rodent model (Markovets et al., 2011a; Markovets et al., 2011b). Mitochondria-specific nanoparticles are also being developed to reduce ROS generation in mitochondria (Weissig et al., 2007).

\subsection{Cell regeneration}

Although amphibians and fish exhibit robust retinal regeneration this, sadly, is not retained in mammals. A number of endogenous stem/progenitor populations have been reported but many, such as retinal stem cells in the ciliary margin zone, remain controversial (Karl and Reh, 2010). A subpopulation of Muller glia with progenitor gene expression have been identified in rodents but there is no definitive evidence that they produce differentiated and functional neurons even though they can express markers for bipolar cells and photoreceptors after injury (Ooto et al., 2004). The clinical approach has been to attempt transplantation of autologous RPE cells or RPE-like cells derived from embryonic stem cells (ESCs) or induced pluripotent stem cells (iPS) (Carr et al., 2009; Du et al., 2011; Lu et al., 2009; Vugler et al., 2007). Human ESC or iPS have the potential to differentiate into rods and cones (Bi et al., 2009; Ikeda et al., 2005; Osakada et al., 2009; Osakada et al., 2007) and can restore light responses when transplanted into the retina of Crx-deficient mice (Lamba et al., 2009a). Although such cells have shown great promise, including visual recovery in a number of animal models of retinal degeneration success with RPE transplantation in humans has to date been modest (Binder et al., 2007; da Cruz et al., 2007). The poor outcome can in part be explained by transplantation being undertaken into eyes with late stage AMD that will have severe retinal degeneration (Binder et al., 2007; Vugler et al., 2007). Repair of the neural retina is more complicated due to the need to form a functional neural network and establish a visual pathway. Success has been achieved using retinal progenitor cells in animal models (MacLaren et al., 2006) but this has yet to be translated to humans.

An alternative source of reparative cells may be derived from the bone marrow which has the potential to differentiate into astrocytes, macrophages/microglia, endothelial cells, pericytes and RPE. However, recruitment and integration appear to occur at a very low level (Chan-Ling et al., 2006; Grant et al., 2002). To overcome this, intravenous injection of bone marrow-derived cells infected ex vivo with lentiviral vector expressing the RPE-specific RPE65 gene resulted in large numbers of cells homing to the neural retina-Bruch's membrane (Sengupta et al., 2009). The recruited cells were able to regenerate a functional RPE layer in sodium iodate treated mice and visual function was restored to that found in normal animals (Sengupta et al., 2009). 


\subsection{Other approaches}

Additional avenues are being investigated. Particular emphasis has focused on mitochondria as these are a major source of ROS in the retina. Of particularly interest is the targeted removal of mitochondria by increasing autophagy which itself appears to be dysregulated in the aged retina (Mitter et al., 2012). Rapamycin is a well established compound for inducing autophagy that acts by inhibiting the mTOR pathway (Bove et al., 2011; Rubinsztein et al., 2011). Rapamycin has been shown to reduce neuronal cell death in a number of retinal models (Bove et al., 2011; Rubinsztein et al., 2011). Other stimulators of autophagy include lithium and trehalose which enhance autophagy via mTOR-independent mechanisms (Sarkar et al., 2007; Sarkar and Rubinsztein, 2006). Unfortunately, despite their potency, rapamycin and lithium have significant side effects which lessen enthusiasm for chronic clinical use (Mizushima et al., 2008; Shacka et al., 2008; Winslow and Rubinsztein, 2008). To overcome small molecule enhancers of rapamycin (SMERs) are being developed that are less toxic. (Sarkar and Rubinsztein, 2008) The efficacy and specificity of compounds that activate autophagy in an mTOR-independent fashion have yet to be established (Shacka et al., 2008; Winslow and Rubinsztein, 2008). Upregulating proteins other than the autophagic pathway proteins, such as caspases and calpains may offer an alternative as they play key roles in cleavage and activation/inactivation of autophagy proteins (reviewed in (Kaminskyy and Zhivotovsky, 2011)). Enhancing mitochondrial biogenesis is another option being considered in neurodegenerative diseases as it has the potential to improve mitochondrial function and may be an important combination therapy to consider in conjunction with enhanced autophagy. Emphasis has been placed on the peroxisome proliferator-activated receptor coactivator 1a (PGC-1a) which controls the nuclear expression of OxPhos components and regulates mitochondrial mtDNA through the mitochondrial transcription factor TFAM (Schon et al., 2010). PKC-1a agonists such as Bezafibrate have shown considerable success in rodent models of mitochondrial disease (Wenz et al., 2008; Yatsuga and Suomalainen, 2012). Improved glycemic index (GI) may offer an alternative approach since rodents on a high GI diet exhibit AMD-like lesions in the retina and this is associated with reduced autophagy and proteolytic activity (Uchiki et al., 2012).

Gene therapy also offers a variety of possibilities since a) enhancement of autophagy by overexpression of Atg7 can protect against anoxia/reoxygenation injury (Kim et al., 2008), b) upregulation of mitochondrial superoxide dismutase restores mitochondrial function and reduces ROS generation in diabetic retinopathy (Kanwar et al., 2007) and c) inhibition of NADPH oxidase by downregulation of p22phox in murine retinal pigment epithelial cells (Li et al., 2008).

Neuroprotection has received considerable attention in the prevention of cell death associated with increased oxidative stress in retinal disease (reviewed in (Barnstable and Tombran-Tink, 2006; Danesh-Meyer, 2011)). However, while delaying the onset of cell death such approaches are limited when used in isolation as they do not remove the cause of the disease.

\section{Concluding remarks and future perspectives}

In this review we have highlighted the susceptibility of the retina to chronic oxidative stress and how this can contribute to age-related retinal cell dysfunction and loss associated with a decline in visual function (summarized in Fig 2). There is strong evidence that oxidative damage can contribute to both the onset and progression of AMD but whether this simply represents an acceleration of the aging process or has a separate etiology is unclear. Current therapeutic strategies are largely focused on increasing antioxidant levels to offset oxidative damage. Although these have met with limited success it is clear that the optimal combination of antioxidants has yet to be formulated and that antioxidant therapy will be 
part of a multifaceted approach in the treatment of AMD. Cellular replacement may also offer an alternative, in particular for late stage disease, to replace damaged or dead cells with new cells that are no longer oxidatively challenged.

\section{Acknowledgments}

This work was supported by NIH grants EY018358, EY019688 and EY021626. The authors wish to thank Lynn Shaw for the art work.

\section{References}

Al-Shabrawey M, Bartoli M, El-Remessy AB, Ma G, Matragoon S, Lemtalsi T, Caldwell RW, Caldwell RB. Role of NADPH oxidase and Stat 3 in statin-mediated protection against diabetic retinopathy. Invest Ophthalmol Vis Sci. 2008; 49 (7):3231-3238. [PubMed: 18378570]

Al-Shabrawey M, Bartoli M, El-Remessy AB, Platt DH, Matragoon S, Behzadian MA, Caldwell RW, Caldwell RB. Inhibition of NAD $(\mathrm{P}) \mathrm{H}$ oxidase activity blocks vascular endothelial growth factor overexpression and neovascularization during ischemic retinopathy. Am J Pathol. 2005; 167 (2): 599-607. [PubMed: 16049343]

Altuntas I, Dane S, Gumustekin K. Effects of cigarette smoking on lipid peroxidation. J Basic Clin Physiol Pharmacol. 2002; 13 (1):69-72. [PubMed: 12099407]

Ames BN. Optimal micronutrients delay mitochondrial decay and age-associated diseases. Mechanisms of ageing and development. 2010; 131 (7-8):473-479. [PubMed: 20420847]

Ames BN, Shigenaga MK. Oxidants are a major contributor to aging. Annals of the New York Academy of Sciences. 1992; 663:85-96. [PubMed: 1482105]

Andreoli CM, Miller JW. Anti-vascular endothelial growth factor therapy for ocular neovascular disease. Curr Opin Ophthalmol. 2007; 18 (6):502-508. [PubMed: 18163003]

Antonenkov VD, Grunau S, Ohlmeier S, Hiltunen JK. Peroxisomes are oxidative organelles. Antioxid Redox Signal. 2010; 13 (4):525-537. [PubMed: 19958170]

Bamonti F, Novembrino C, Ippolito S, Soresi E, Ciani A, Lonati S, Scurati-Manzoni E, Cighetti G. Increased free malondialdehyde concentrations in smokers normalise with a mixed fruit and vegetable juice concentrate: a pilot study. Clin Chem Lab Med. 2006; 44 (4):391-395. [PubMed: 16599830]

Barnstable CJ, Tombran-Tink J. Molecular mechanisms of neuroprotection in the eye. Advances in experimental medicine and biology. 2006; 572:291-295. [PubMed: 17249586]

Beatty S, Koh H, Phil M, Henson D, Boulton M. The role of oxidative stress in the pathogenesis of age-related macular degeneration. Survey of ophthalmology. 2000; 45 (2):115-134. [PubMed: 11033038]

Beatty S, Murray IJ, Henson DB, Carden D, Koh H, Boulton ME. Macular pigment and risk for agerelated macular degeneration in subjects from a Northern European population. Invest Ophthalmol Vis Sci. 2001; 42 (2):439-446. [PubMed: 11157880]

Beckman JS. Oxidative damage and tyrosine nitration from peroxynitrite. Chemical research in toxicology. 1996; 9 (5):836-844. [PubMed: 8828918]

Beckman KB, Ames BN. The free radical theory of aging matures. Physiological reviews. 1998; 78 (2):547-581. [PubMed: 9562038]

Bedard K, Krause KH. The NOX family of ROS-generating NADPH oxidases: physiology and pathophysiology. Physiological reviews. 2007; 87 (1):245-313. [PubMed: 17237347]

Bensasson, RV.; Land, E.; Truscott, TG. Contributions from Flash Photolysis and Pulse Radiolysis. Oxford University Press; Oxford: 1993. Excited States and Free Radicals in Biology and Medicine.

Bi YY, Feng DF, Pan DC. Stem/progenitor cells: a potential source of retina-specific cells for retinal repair. Neurosci Res. 2009; 65 (3):215-221. [PubMed: 19647023]

Binder S, Stanzel BV, Krebs I, Glittenberg C. Transplantation of the RPE in AMD. Prog Retin Eye Res. 2007; 26 (5):516-554. [PubMed: 17532250] 
Blank LM, Ebert BE, Buehler K, Buhler B. Redox biocatalysis and metabolism: molecular mechanisms and metabolic network analysis. Antioxid Redox Signal. 2010; 13 (3):349-394. [PubMed: 20059399]

Bohr V, Anson RM, Mazur S, Dianov G. Oxidative DNA damage processing and changes with aging. Toxicology letters. 1998:102-103. 47-52.

Bohr VA, Ottersen OP, Tonjum T. Genome instability and DNA repair in brain, ageing and neurological disease. Neuroscience. 2007; 145 (4):1183-1186. [PubMed: 17400394]

Bonekamp NA, Volkl A, Fahimi HD, Schrader M. Reactive oxygen species and peroxisomes: struggling for balance. Biofactors. 2009; 35 (4):346-355. [PubMed: 19459143]

Boulton, M. Lipofuscin of the retinal pigment epithelium. In: Lois, N.; Forrester, JV., editors. Fundus Autofluorescence. Lippincott Williams and Wilkins; Philadelphia: 2009. p. 14-26.

Boulton M, Rozanowska M, Rozanowski B. Retinal photodamage. J Photochem Photobiol B. 2001; 64 (2-3):144-161. [PubMed: 11744401]

Bove J, Martinez-Vicente M, Vila M. Fighting neurodegeneration with rapamycin: mechanistic insights. Nature reviews. Neuroscience. 2011; 12 (8):437-452. [PubMed: 21772323]

Braca A, Dal Piaz F, Marzocco S, Autore G, Vassallo A, De Tommasi N. Triterpene derivatives as inhibitors of protein involved in the inflammatory process: molecules interfering with phospholipase A2, cycloxygenase, and lipoxygenase. Current drug targets. 2011; 12 (3):302-321. [PubMed: 20955150]

Brand MD, Affourtit C, Esteves TC, Green K, Lambert AJ, Miwa S, Pakay JL, Parker N. Mitochondrial superoxide: production, biological effects, and activation of uncoupling proteins. Free radical biology \& medicine. 2004; 37 (6):755-767. [PubMed: 15304252]

Breen AP, Murphy JA. Reactions of oxyl radicals with DNA. Free radical biology \& medicine. 1995; 18 (6):1033-1077. [PubMed: 7628729]

Bylund J, Brown KL, Movitz C, Dahlgren C, Karlsson A. Intracellular generation of superoxide by the phagocyte NADPH oxidase: how, where, and what for? Free radical biology \& medicine. 2010; 49 (12):1834-1845. [PubMed: 20870019]

Cameron JM, Levandovskiy V, Mackay N, Ackerley C, Chitayat D, Raiman J, Halliday WH, Schulze A, Robinson BH. Complex V TMEM70 deficiency results in mitochondrial nucleoid disorganization. Mitochondrion. 2011; 11 (1):191-199. [PubMed: 20920610]

Cantin AM. Cellular response to cigarette smoke and oxidants: adapting to survive. Proceedings of the American Thoracic Society. 2010; 7 (6):368-375. [PubMed: 21030515]

Cantu D, Fulton RE, Drechsel DA, Patel M. Mitochondrial aconitase knockdown attenuates paraquatinduced dopaminergic cell death via decreased cellular metabolism and release of iron and HO. Journal of neurochemistry. 2011; 118 (1):79-92. [PubMed: 21517855]

Carr AJ, Vugler AA, Hikita ST, Lawrence JM, Gias C, Chen LL, Buchholz DE, Ahmado A, Semo M, Smart MJ, Hasan S, da Cruz L, Johnson LV, Clegg DO, Coffey PJ. Protective effects of human iPS-derived retinal pigment epithelium cell transplantation in the retinal dystrophic rat. PloS one. 2009; 4 (12):e8152. [PubMed: 19997644]

Castorina C, Campisi A, Di Giacomo C, Sorrenti V, Russo A, Vanella A. Lipid peroxidation and antioxidant enzymatic systems in rat retina as a function of age. Neurochem Res. 1992; 17 (6): 599-604. [PubMed: 1603266]

Catala A. Lipid peroxidation of membrane phospholipids in the vertebrate retina. Front Biosci (Schol Ed). 2011; 3:52-60. [PubMed: 21196356]

Chan-Ling T, Baxter L, Afzal A, Sengupta N, Caballero S, Rosinova E, Grant MB. Hematopoietic stem cells provide repair functions after laser-induced Bruch's membrane rupture model of choroidal neovascularization. Am J Pathol. 2006; 168 (3):1031-1044. [PubMed: 16507916]

Chaturvedi RK, Beal MF. Mitochondrial approaches for neuroprotection. Annals of the New York Academy of Sciences. 2008; 1147:395-412. [PubMed: 19076459]

Collier RJ, Patel Y, Martin EA, Dembinska O, Hellberg M, Krueger DS, Kapin MA, Romano C. Agonists at the serotonin receptor (5-HT(1A)) protect the retina from severe photo-oxidative stress. Invest Ophthalmol Vis Sci. 2011a; 52 (5):2118-2126. [PubMed: 21087971] 
Collier RJ, Wang Y, Smith SS, Martin E, Ornberg R, Rhoades K, Romano C. Complement deposition and microglial activation in the outer retina in light-induced retinopathy: inhibition by a 5-HT1A agonist. Invest Ophthalmol Vis Sci. 2011b; 52 (11):8108-8116. [PubMed: 21467172]

Comporti M. Lipid peroxidation and biogenic aldehydes: from the identification of 4-hydroxynonenal to further achievements in biopathology. Free radical research. 1998; 28 (6):623-635. [PubMed: 9736314]

Cortes-Rojo C, Rodriguez-Orozco AR. Importance of oxidative damage on the electron transport chain for the rational use of mitochondria-targeted antioxidants. Mini Rev Med Chem. 2011; 11 (7):625632. [PubMed: 21699493]

Crabb JW, Miyagi M, Gu X, Shadrach K, West KA, Sakaguchi H, Kamei M, Hasan A, Yan L, Rayborn ME, Salomon RG, Hollyfield JG. Drusen proteome analysis: an approach to the etiology of age-related macular degeneration. Proceedings of the National Academy of Sciences of the United States of America. 2002; 99 (23):14682-14687. [PubMed: 12391305]

Crawford DR, Davies KJ. Adaptive response and oxidative stress. Environ Health Perspect. 1994; 102(Suppl 10):25-28. [PubMed: 7705299]

da Cruz L, Chen FK, Ahmado A, Greenwood J, Coffey P. RPE transplantation and its role in retinal disease. Prog Retin Eye Res. 2007; 26 (6):598-635. [PubMed: 17920328]

Danesh-Meyer HV. Neuroprotection in glaucoma: recent and future directions. Curr Opin Ophthalmol. 2011; 22 (2):78-86. [PubMed: 21252670]

Davies KJ. Degradation of oxidized proteins by the 20S proteasome. Biochimie. 2001; 83 (3-4):301310. [PubMed: 11295490]

Davies S, Elliott MH, Floor E, Truscott TG, Zareba M, Sarna T, Shamsi FA, Boulton ME. Photocytotoxicity of lipofuscin in human retinal pigment epithelial cells. Free radical biology \& medicine. 2001; 31 (2):256-265. [PubMed: 11440838]

de Jong PT. Age-related macular degeneration. The New England journal of medicine. 2006; 355 (14): 1474-1485. [PubMed: 17021323]

Delcourt C, Delyfer MN, Rougier MB, Amouyel P, Colin J, Le Goff M, Malet F, Dartigues JF, Lambert JC, Korobelnik JF. Associations of complement factor $\mathrm{H}$ and smoking with early agerelated macular degeneration: the ALIENOR study. Invest Ophthalmol Vis Sci. 2011; 52 (8): 5955-5962. [PubMed: 21642625]

Desouki MM, Kulawiec M, Bansal S, Das GM, Singh KK. Cross talk between mitochondria and superoxide generating NADPH oxidase in breast and ovarian tumors. Cancer biology \& therapy. 2005; 4 (12):1367-1373. [PubMed: 16294028]

Dianov GL, Souza-Pinto N, Nyaga SG, Thybo T, Stevnsner T, Bohr VA. Base excision repair in nuclear and mitochondrial DNA. Prog Nucleic Acid Res Mol Biol. 2001; 68:285-297. [PubMed: 11554304]

Dikalova AE, Bikineyeva AT, Budzyn K, Nazarewicz RR, McCann L, Lewis W, Harrison DG, Dikalov SI. Therapeutic targeting of mitochondrial superoxide in hypertension. Circulation research. 2010; 107 (1):106-116. [PubMed: 20448215]

Ding X, Patel M, Chan CC. Molecular pathology of age-related macular degeneration. Prog Retin Eye Res. 2009; 28 (1):1-18. [PubMed: 19026761]

Dizdaroglu M, Jaruga P, Birincioglu M, Rodriguez H. Free radical-induced damage to DNA: mechanisms and measurement. Free radical biology \& medicine. 2002; 32 (11):1102-1115. [PubMed: 12031895]

Du H, Lim SL, Grob S, Zhang K. Induced pluripotent stem cell therapies for geographic atrophy of age-related macular degeneration. Semin Ophthalmol. 2011; 26 (3):216-224. [PubMed: 21609235]

Esfandiary H, Chakravarthy U, Patterson C, Young I, Hughes AE. Association study of detoxification genes in age related macular degeneration. The British journal of ophthalmology. 2005; 89 (4): 470-474. [PubMed: 15774926]

Espinosa-Heidmann DG, Suner IJ, Catanuto P, Hernandez EP, Marin-Castano ME, Cousins SW. Cigarette smoke-related oxidants and the development of sub-RPE deposits in an experimental animal model of dry AMD. Invest Ophthalmol Vis Sci. 2006; 47 (2):729-737. [PubMed: 16431974] 
Esterbauer H, Schaur RJ, Zollner H. Chemistry and biochemistry of 4-hydroxynonenal, malonaldehyde and related aldehydes. Free radical biology \& medicine. 1991; 11 (1):81-128. [PubMed: 1937131]

Feher J, Papale A, Mannino G, Gualdi L, Balacco Gabrieli C. Mitotropic compounds for the treatment of age-related macular degeneration. The metabolic approach and a pilot study. Ophthalmologica. Journal international d'ophtalmologie. International journal of ophthalmology. Zeitschrift fur Augenheilkunde. 2003; 217 (5):351-357. [PubMed: 12913326]

Fridovich I. Superoxide anion radical $\left(\mathrm{O}^{-}{ }^{-}\right)$, superoxide dismutases, and related matters. The Journal of biological chemistry. 1997; 272 (30):18515-18517. [PubMed: 9228011]

Friedman DS, O'Colmain BJ, Munoz B, Tomany SC, McCarty C, de Jong PT, Nemesure B, Mitchell $\mathrm{P}$, Kempen J. Prevalence of age-related macular degeneration in the United States. Arch Ophthalmol. 2004; 122 (4):564-572. [PubMed: 15078675]

Friedrichson T, Kalbach HL, Buck P, van Kuijk FJ. Vitamin E in macular and peripheral tissues of the human eye. Curr Eye Res. 1995; 14 (8):693-701. [PubMed: 8529405]

Gabriel HE, Liu Z, Crott JW, Choi SW, Song BC, Mason JB, Johnson EJ. A comparison of carotenoids, retinoids, and tocopherols in the serum and buccal mucosa of chronic cigarette smokers versus nonsmokers. Cancer Epidemiol Biomarkers Prev. 2006; 15 (5):993-999. [PubMed: 16702382]

Gaillard ER, Atherton SJ, Eldred G, Dillon J. Photophysical studies on human retinal lipofuscin. Photochemistry and photobiology. 1995; 61 (5):448-453. [PubMed: 7770505]

Galan P, Viteri FE, Bertrais S, Czernichow S, Faure H, Arnaud J, Ruffieux D, Chenal S, Arnault N, Favier A, Roussel AM, Hercberg S. Serum concentrations of beta-carotene, vitamins C and E, zinc and selenium are influenced by sex, age, diet, smoking status, alcohol consumption and corpulence in a general French adult population. Eur J Clin Nutr. 2005; 59 (10):1181-1190. [PubMed: 16034362]

Glenn JV, Stitt AW. The role of advanced glycation end products in retinal ageing and disease. Biochimica et biophysica acta. 2009; 1790 (10):1109-1116. [PubMed: 19409449]

Godley BF, Jin GF, Guo YS, Hurst JS. Bcl-2 overexpression increases survival in human retinal pigment epithelial cells exposed to $\mathrm{H}(2) \mathrm{O}(2)$. Experimental eye research. 2002; 74 (6):663-669. [PubMed: 12126940]

Godley BF, Shamsi FA, Liang FQ, Jarrett SG, Davies S, Boulton M. Blue light induces mitochondrial DNA damage and free radical production in epithelial cells. The Journal of biological chemistry. 2005; 280 (22):21061-21066. [PubMed: 15797866]

Gomez-Cabrera MC, Vina J, Ji LL. Interplay of oxidants and antioxidants during exercise: implications for muscle health. The Physician and sportsmedicine. 2009; 37 (4):116-123. [PubMed: 20048548]

Gorgun E, Guven M, Unal M, Batar B, Guven GS, Yenerel M, Tatlipinar S, Seven M, Yuksel A. Polymorphisms of the DNA repair genes XPD and XRCC1 and the risk of age-related macular degeneration. Invest Ophthalmol Vis Sci. 2010; 51 (9):4732-4737. [PubMed: 20375340]

Grant MB, May WS, Caballero S, Brown GA, Guthrie SM, Mames RN, Byrne BJ, Vaught T, Spoerri $\mathrm{PE}$, Peck AB, Scott EW. Adult hematopoietic stem cells provide functional hemangioblast activity during retinal neovascularization. Nat Med. 2002; 8 (6):607-612. [PubMed: 12042812]

Graziewicz MA, Day BJ, Copeland WC. The mitochondrial DNA polymerase as a target of oxidative damage. Nucleic acids research. 2002; 30 (13):2817-2824. [PubMed: 12087165]

Grimm C, Wenzel A, Williams T, Rol P, Hafezi F, Reme C. Rhodopsin-mediated blue-light damage to the rat retina: effect of photoreversal of bleaching. Invest Ophthalmol Vis Sci. 2001; 42 (2):497505. [PubMed: 11157889]

Gu X, Meer SG, Miyagi M, Rayborn ME, Hollyfield JG, Crabb JW, Salomon RG. Carboxyethylpyrrole protein adducts and autoantibodies, biomarkers for age-related macular degeneration. The Journal of biological chemistry. 2003; 278 (43):42027-42035. [PubMed: 12923198]

Gutteridge JM, Halliwell B. Free radicals and antioxidants in the year 2000. A historical look to the future. Annals of the New York Academy of Sciences. 2000; 899:136-147. [PubMed: 10863535] 
Guven M, Gorgun E, Unal M, Yenerel M, Batar B, Kucumen B, Dinc UA, Guven GS, Ulus T, Yuksel A. Glutathione S-transferase M1, GSTT1 and GSTP1 genetic polymorphisms and the risk of agerelated macular degeneration. Ophthalmic Res. 2011; 46 (1):31-37. [PubMed: 21212706]

Halliwell B, Dizdaroglu M. The measurement of oxidative damage to DNA by HPLC and GC/MS techniques. Free radical research communications. 1992; 16 (2):75-87. [PubMed: 1321076]

Halliwell, B.; Gutteridge, JM. Free Radicals in Biology and Medicine. 3. Oxford University Press; New York: 1999.

Ham WT Jr, Mueller HA, Ruffolo JJ Jr, Millen JE, Cleary SF, Guerry RK, Guerry D 3rd. Basic mechanisms underlying the production of photochemical lesions in the mammalian retina. Curr Eye Res. 1984; 3 (1):165-174. [PubMed: 6690219]

Harman D. Aging: a theory based on free radical and radiation chemistry. Journal of gerontology. 1956; 11 (3):298-300. [PubMed: 13332224]

Harman D. The biologic clock: the mitochondria? Journal of the American Geriatrics Society. 1972; 20 (4):145-147. [PubMed: 5016631]

Harrison JF, Hollensworth SB, Spitz DR, Copeland WC, Wilson GL, LeDoux SP. Oxidative stressinduced apoptosis in neurons correlates with mitochondrial DNA base excision repair pathway imbalance. Nucleic acids research. 2005; 33 (14):4660-4671. [PubMed: 16107556]

Hartnett ME. The effects of oxygen stresses on the development of features of severe retinopathy of prematurity: knowledge from the 50/10 OIR model. Doc Ophthalmol. 2010; 120:25-39. [PubMed: 19639355]

Helmersson J, Larsson A, Vessby B, Basu S. Active smoking and a history of smoking are associated with enhanced prostaglandin F(2alpha), interleukin-6 and F2-isoprostane formation in elderly men. Atherosclerosis. 2005; 181 (1):201-207. [PubMed: 15939073]

Ikeda H, Osakada F, Watanabe K, Mizuseki K, Haraguchi T, Miyoshi H, Kamiya D, Honda Y, Sasai N, Yoshimura N, Takahashi M, Sasai Y. Generation of Rx+/Pax6+ neural retinal precursors from embryonic stem cells. Proceedings of the National Academy of Sciences of the United States of America. 2005; 102 (32):11331-11336. [PubMed: 16076961]

Imamura Y, Noda S, Hashizume K, Shinoda K, Yamaguchi M, Uchiyama S, Shimizu T, Mizushima Y, Shirasawa T, Tsubota K. Drusen, choroidal neovascularization, and retinal pigment epithelium dysfunction in SOD1-deficient mice: a model of age-related macular degeneration. Proceedings of the National Academy of Sciences of the United States of America. 2006; 103 (30):11282-11287. [PubMed: 16844785]

Ivashchenko O, Van Veldhoven PP, Brees C, Ho YS, Terlecky SR, Fransen M. Intraperoxisomal redox balance in mammalian cells: oxidative stress and interorganellar cross-talk. Molecular biology of the cell. 2011; 22 (9):1440-1451. [PubMed: 21372177]

Jackson MJ. Reactive oxygen species and redox-regulation of skeletal muscle adaptations to exercise. Philosophical transactions of the Royal Society of London. Series B, Biological sciences. 2005; 360 (1464):2285-2291.

Jahngen-Hodge J, Obin MS, Gong X, Shang F, Nowell TR Jr, Gong J, Abasi H, Blumberg J, Taylor A. Regulation of ubiquitin-conjugating enzymes by glutathione following oxidative stress. The Journal of biological chemistry. 1997; 272 (45):28218-28226. [PubMed: 9353272]

Jarrett SG, Albon J, Boulton M. The contribution of DNA repair and antioxidants in determining cell type-specific resistance to oxidative stress. Free radical research. 2006a; 40 (11):1155-1165. [PubMed: 17050169]

Jarrett SG, Boulton ME. Antioxidant up-regulation and increased nuclear DNA protection play key roles in adaptation to oxidative stress in epithelial cells. Free radical biology \& medicine. 2005; 38 (10):1382-1391. [PubMed: 15855056]

Jarrett SG, Boulton ME. Poly(ADP-ribose) polymerase offers protection against oxidative and alkylation damage to the nuclear and mitochondrial genomes of the retinal pigment epithelium. Ophthalmic Res. 2007; 39 (4):213-223. [PubMed: 17596754]

Jarrett SG, Cuenco J, Boulton M. Dietary antioxidants provide differential subcellular protection in epithelial cells. Redox report : communications in free radical research. 2006b; 11 (4):144-152. [PubMed: 16984736] 
Jarrett SG, Lewin AS, Boulton ME. The importance of mitochondria in age-related and inherited eye disorders. Ophthalmic Res. 2010; 44 (3):179-190. [PubMed: 20829642]

Jarrett SG, Lin H, Godley BF, Boulton ME. Mitochondrial DNA damage and its potential role in retinal degeneration. Prog Retin Eye Res. 2008; 27 (6):596-607. [PubMed: 18848639]

Jin GF, Hurst JS, Godley BF. Rod outer segments mediate mitochondrial DNA damage and apoptosis in human retinal pigment epithelium. Curr Eye Res. 2001; 23 (1):11-19. [PubMed: 11821981]

Jomova K, Vondrakova D, Lawson M, Valko M. Metals, oxidative stress and neurodegenerative disorders. Mol Cell Biochem. 2010; 345 (1-2):91-104. [PubMed: 20730621]

Jones DP. Redefining oxidative stress. Antioxid Redox Signal. 2006; 8 (9-10):1865-1879. [PubMed: 16987039]

Jones M, Mitchell P, Wang JJ, Sue C. MELAS A3243G mitochondrial DNA mutation and age related maculopathy. American journal of ophthalmology. 2004; 138 (6):1051-1053. [PubMed: 15629304]

Jones MM, Manwaring N, Wang JJ, Rochtchina E, Mitchell P, Sue CM. Mitochondrial DNA haplogroups and age-related maculopathy. Arch Ophthalmol. 2007; 125 (9):1235-1240. [PubMed: 17846364]

Justilien V, Pang JJ, Renganathan K, Zhan X, Crabb JW, Kim SR, Sparrow JR, Hauswirth WW, Lewin AS. SOD2 knockdown mouse model of early AMD. Invest Ophthalmol Vis Sci. 2007; 48 (10):4407-4420. [PubMed: 17898259]

Kalariya NM, Ramana KV, Srivastava SK, van Kuijk FJ. Genotoxic effects of carotenoid breakdown products in human retinal pigment epithelial cells. Curr Eye Res. 2009; 34 (9):737-747. [PubMed: 19839867]

Kaminskyy V, Zhivotovsky B. Proteases in autophagy. Biochimica et biophysica acta. 2011

Kanda A, Chen W, Othman M, Branham KE, Brooks M, Khanna R, He S, Lyons R, Abecasis GR, Swaroop A. A variant of mitochondrial protein LOC387715/ARMS2, not HTRA1, is strongly associated with age-related macular degeneration. Proceedings of the National Academy of Sciences of the United States of America. 2007; 104 (41):16227-16232. [PubMed: 17884985]

Kanda A, Stambolian D, Chen W, Curcio CA, Abecasis GR, Swaroop A. Age-related macular degeneration-associated variants at chromosome 10q26 do not significantly alter ARMS2 and HTRA1 transcript levels in the human retina. Molecular vision. 2010; 16:1317-1323. [PubMed: 20664794]

Kanwar M, Chan PS, Kern TS, Kowluru RA. Oxidative damage in the retinal mitochondria of diabetic mice: possible protection by superoxide dismutase. Invest Ophthalmol Vis Sci. 2007; 48 (8): 3805-3811. [PubMed: 17652755]

Karl MO, Reh TA. Regenerative medicine for retinal diseases: activating endogenous repair mechanisms. Trends Mol Med. 2010; 16 (4):193-202. [PubMed: 20303826]

Karunadharma PP, Nordgaard CL, Olsen TW, Ferrington DA. Mitochondrial DNA damage as a potential mechanism for age-related macular degeneration. Invest Ophthalmol Vis Sci. 2010; 51 (11):5470-5479. [PubMed: 20505194]

Kasahara E, Lin LR, Ho YS, Reddy VN. SOD2 protects against oxidation-induced apoptosis in mouse retinal pigment epithelium: implications for age-related macular degeneration. Invest Ophthalmol Vis Sci. 2005; 46 (9):3426-3434. [PubMed: 16123448]

Kenney MC, Atilano SR, Boyer D, Chwa M, Chak G, Chinichian S, Coskun P, Wallace DC, Nesburn AB, Udar NS. Characterization of retinal and blood mitochondrial DNA from age-related macular degeneration patients. Invest Ophthalmol Vis Sci. 2010; 51 (8):4289-4297. [PubMed: 20357205]

Khandhadia S, Lotery A. Oxidation and age-related macular degeneration: insights from molecular biology. Expert Rev Mol Med. 2010; 12:e34. [PubMed: 20959033]

Kim JS, Nitta T, Mohuczy D, O’Malley KA, Moldawer LL, Dunn WA Jr, Behrns KE. Impaired autophagy: A mechanism of mitochondrial dysfunction in anoxic rat hepatocytes. Hepatology. 2008; 47 (5):1725-1736. [PubMed: 18311843]

Kim SH, Kim JS, Shin HS, Keen CL. Influence of smoking on markers of oxidative stress and serum mineral concentrations in teenage girls in Korea. Nutrition. 2003; 19 (3):240-243. [PubMed: 12620526] 
Kimura K, Isashiki Y, Sonoda S, Kakiuchi-Matsumoto T, Ohba N. Genetic association of manganese superoxide dismutase with exudative age-related macular degeneration. American journal of ophthalmology. 2000; 130 (6):769-773. [PubMed: 11124296]

King A, Gottlieb E, Brooks DG, Murphy MP, Dunaief JL. Mitochondria-derived reactive oxygen species mediate blue light-induced death of retinal pigment epithelial cells. Photochemistry and photobiology. 2004; 79 (5):470-475. [PubMed: 15191057]

Kong Q, Lin CL. Oxidative damage to RNA: mechanisms, consequences, and diseases. Cellular and molecular life sciences : CMLS. 2010; 67 (11):1817-1829. [PubMed: 20148281]

Kong Q, Shan X, Chang Y, Tashiro H, Lin CL. RNA oxidation: a contributing factor or an epiphenomenon in the process of neurodegeneration. Free radical research. 2008; 42 (9):773777. [PubMed: 18661427]

Kopitz J, Holz FG, Kaemmerer E, Schutt F. Lipids and lipid peroxidation products in the pathogenesis of age-related macular degeneration. Biochimie. 2004; 86 (11):825-831. [PubMed: 15589692]

Koppenol WH. The Haber-Weiss cycle--70 years later. Redox report : communications in free radical research. 2001; 6 (4):229-234. [PubMed: 11642713]

Kowalski M, Bielecka-Kowalska A, Oszajca K, Makandjou-Ola E, Jaworski P, Bartkowiak J, Szemraj J. Manganese superoxide dismutase (MnSOD) gene (Ala-9Val, Ile58Thr) polymorphism in patients with age-related macular degeneration (AMD). Medical science monitor : international medical journal of experimental and clinical research. 2010; 16(4):CR190-196. [PubMed: 20357718]

Kowluru RA, Kanwar M. Effects of curcumin on retinal oxidative stress and inflammation in diabetes. Nutr Metab (Lond). 2007; 4:8. [PubMed: 17437639]

Kruft BI, Greer A. Photosensitization reactions in vitro and in vivo. Photochemistry and photobiology. 2011; 87 (6):1204-1213. [PubMed: 21883245]

Lamba DA, Gust J, Reh TA. Transplantation of human embryonic stem cell-derived photoreceptors restores some visual function in Crx-deficient mice. Cell Stem Cell. 2009a; 4 (1):73-79. [PubMed: 19128794]

Lamba DA, Karl MO, Reh TA. Strategies for retinal repair: cell replacement and regeneration. Prog Brain Res. 2009b; 175:23-31. [PubMed: 19660646]

Leonarduzzi G, Sottero B, Testa G, Biasi F, Poli G. New insights into redox-modulated cell signaling. Current pharmaceutical design. 2011; 17 (36):3994-4006. [PubMed: 22188450]

Li L, Renier G. Activation of nicotinamide adenine dinucleotide phosphate (reduced form) oxidase by advanced glycation end products links oxidative stress to altered retinal vascular endothelial growth factor expression. Metabolism. 2006; 55 (11):1516-1523. [PubMed: 17046555]

Li Q, Dinculescu A, Shan Z, Miller R, Pang J, Lewin AS, Raizada MK, Hauswirth WW. Downregulation of $\mathrm{p} 22$ phox in retinal pigment epithelial cells inhibits choroidal neovascularization in mice. Molecular therapy : the journal of the American Society of Gene Therapy. 2008; 16 (10):1688-1694. [PubMed: 18665154]

Liang FQ, Alssadi R, Morehead P, Awasthi YC, Godley BF. Enhanced expression of glutathione-Stransferase A1-1 protects against oxidative stress in human retinal pigment epithelial cells. Experimental eye research. 2005; 80 (1):113-119. [PubMed: 15652532]

Liang FQ, Godley BF. Oxidative stress-induced mitochondrial DNA damage in human retinal pigment epithelial cells: a possible mechanism for RPE aging and age-related macular degeneration. Experimental eye research. 2003; 76 (4):397-403. [PubMed: 12634104]

Liang FQ, Green L, Wang C, Alssadi R, Godley BF. Melatonin protects human retinal pigment epithelial (RPE) cells against oxidative stress. Experimental eye research. 2004; 78 (6):10691075. [PubMed: 15109913]

Liao JH, Lee JS, Chiou SH. C-terminal lysine truncation increases thermostability and enhances chaperone-like function of porcine alphaB-crystallin. Biochem Biophys Res Commun. 2002; 297 (2):309-316. [PubMed: 12237119]

Liles MR, Newsome DA, Oliver PD. Antioxidant enzymes in the aging human retinal pigment epithelium. Arch Ophthalmol. 1991; 109 (9):1285-1288. [PubMed: 1929958] 
Lin H, Qian J, Castillo AC, Long B, Keyes KT, Chen G, Ye Y. Effect of miR-23 on oxidant-induced injury in human retinal pigment epithelial cells. Invest Ophthalmol Vis Sci. 2011a; 52 (9):63086314. [PubMed: 21693609]

Lin H, Xu H, Liang FQ, Liang H, Gupta P, Havey AN, Boulton ME, Godley BF. Mitochondrial DNA damage and repair in RPE associated with aging and age-related macular degeneration. Invest Ophthalmol Vis Sci. 2011b; 52 (6):3521-3529. [PubMed: 21273542]

Liochev SI, Fridovich I. The Haber-Weiss cycle -- 70 years later: an alternative view. Redox report : communications in free radical research. 2002; 7(1):55-57. author reply 59-60. [PubMed: 11981456]

Liu J, Atamna H, Kuratsune H, Ames BN. Delaying brain mitochondrial decay and aging with mitochondrial antioxidants and metabolites. Annals of the New York Academy of Sciences. 2002; 959:133-166. [PubMed: 11976193]

Lowe GM, Vlismas K, Young AJ. Carotenoids as prooxidants? Mol Aspects Med. 2003; 24 (6):363369. [PubMed: 14585307]

Lu B, Malcuit C, Wang S, Girman S, Francis P, Lemieux L, Lanza R, Lund R. Long-term safety and function of RPE from human embryonic stem cells in preclinical models of macular degeneration. Stem Cells. 2009; 27 (9):2126-2135. [PubMed: 19521979]

MacLaren RE, Pearson RA, MacNeil A, Douglas RH, Salt TE, Akimoto M, Swaroop A, Sowden JC, Ali RR. Retinal repair by transplantation of photoreceptor precursors. Nature. 2006; 444 (7116): 203-207. [PubMed: 17093405]

Maeda A, Crabb JW, Palczewski K. Microsomal glutathione S-transferase 1 in the retinal pigment epithelium: protection against oxidative stress and a potential role in aging. Biochemistry. 2005; 44 (2):480-489. [PubMed: 15641772]

Markovets AM, Fursova AZ, Kolosova NG. Therapeutic action of the mitochondria-targeted antioxidant SkQ1 on retinopathy in OXYS rats linked with improvement of VEGF and PEDF gene expression. PloS one. 2011a; 6 (7):e21682. [PubMed: 21750722]

Markovets AM, Saprunova VB, Zhdankina AA, Fursova A, Bakeeva LE, Kolosova NG. Alterations of retinal pigment epithelium cause AMD-like retinopathy in senescence-accelerated OXYS rats. Aging. 2011b; 3 (1):44-54. [PubMed: 21191149]

McCord JM, Fridovich I. Superoxide dismutase. An enzymic function for erythrocuprein (hemocuprein). The Journal of biological chemistry. 1969a; 244 (22):6049-6055. [PubMed: 5389100]

McCord JM, Fridovich I. The utility of superoxide dismutase in studying free radical reactions. I. Radicals generated by the interaction of sulfite, dimethyl sulfoxide, and oxygen. The Journal of biological chemistry. 1969b; 244 (22):6056-6063. [PubMed: 4981789]

Mellerio, J. Light effect on the retina. In: Albert, D.; Jakobiec, F., editors. Principles and Practice in Ophthalmology. W.B. Saunders; Philadelphia: 1994. p. 1326-1345.

Miceli MV, Liles MR, Newsome DA. Evaluation of oxidative processes in human pigment epithelial cells associated with retinal outer segment phagocytosis. Exp Cell Res. 1994; 214 (1):242-249. [PubMed: 8082727]

Mitter SK, Rao HV, Qi X, Cai J, Sugrue A, Dunn WA Jr, Grant MB, Boulton ME. Autophagy in the retina: a potential role in age-related macular degeneration. Advances in experimental medicine and biology. 2012; 723:83-90. [PubMed: 22183319]

Miyamura N, Ogawa T, Boylan S, Morse LS, Handa JT, Hjelmeland LM. Topographic and agedependent expression of heme oxygenase- 1 and catalase in the human retinal pigment epithelium. Invest Ophthalmol Vis Sci. 2004; 45 (5):1562-1565. [PubMed: 15111615]

Mizushima N, Levine B, Cuervo AM, Klionsky DJ. Autophagy fights disease through cellular selfdigestion. Nature. 2008; 451 (7182):1069-1075. [PubMed: 18305538]

Montezuma SR, Sobrin L, Seddon JM. Review of genetics in age related macular degeneration. Semin Ophthalmol. 2007; 22 (4):229-240. [PubMed: 18097986]

Murphy RT, Foley JB, Tome MT, Mulvihill NT, Murphy A, McCarroll N, Crean P, Walsh MJ. Vitamin E modulation of C-reactive protein in smokers with acute coronary syndromes. Free radical biology \& medicine. 2004; 36 (8):959-965. [PubMed: 15059636] 
Negre-Salvayre A, Coatrieux C, Ingueneau C, Salvayre R. Advanced lipid peroxidation end products in oxidative damage to proteins. Potential role in diseases and therapeutic prospects for the inhibitors. Br J Pharmacol. 2008; 153 (1):6-20. [PubMed: 17643134]

Ni Dhubhghaill SS, Cahill MT, Campbell M, Cassidy L, Humphries MM, Humphries P. The pathophysiology of cigarette smoking and age-related macular degeneration. Advances in experimental medicine and biology. 2010; 664:437-446. [PubMed: 20238045]

Noell WK, Albrecht R. Irreversible effects on visible light on the retina: role of vitamin A. Science. 1971; 172 (3978):76-79. [PubMed: 5546288]

Noell WK, Walker VS, Kang BS, Berman S. Retinal damage by light in rats. Invest Ophthalmol. 1966; 5 (5):450-473. [PubMed: 5929286]

Obin M, Shang F, Gong X, Handelman G, Blumberg J, Taylor A. Redox regulation of ubiquitinconjugating enzymes: mechanistic insights using the thiol-specific oxidant diamide. The FASEB journal : official publication of the Federation of American Societies for Experimental Biology. 1998; 12 (7):561-569.

Ooto S, Akagi T, Kageyama R, Akita J, Mandai M, Honda Y, Takahashi M. Potential for neural regeneration after neurotoxic injury in the adult mammalian retina. Proceedings of the National Academy of Sciences of the United States of America. 2004; 101 (37):13654-13659. [PubMed: 15353594]

Organisciak D, Darrow R, Gu X, Barsalou L, Crabb JW. Genetic, age and light mediated effects on crystallin protein expression in the retina. Photochemistry and photobiology. 2006; 82 (4):10881096. [PubMed: 16602829]

Organisciak DT, Noell WK. The rod outer segment phospholipid/opsin ratio of rats maintained in darkness or cyclic light. Invest Ophthalmol Vis Sci. 1977; 16 (2):188-190. [PubMed: 832982]

Osakada F, Ikeda H, Sasai Y, Takahashi M. Stepwise differentiation of pluripotent stem cells into retinal cells. Nat Protoc. 2009; 4 (6):811-824. [PubMed: 19444239]

Osakada F, Ooto S, Akagi T, Mandai M, Akaike A, Takahashi M. Wnt signaling promotes regeneration in the retina of adult mammals. J Neurosci. 2007; 27 (15):4210-4219. [PubMed: 17428999]

Oz O, Aras Ates N, Tamer L, Yildirim O, Adiguzel U. Glutathione S-transferase M1, T1, and P1 gene polymorphism in exudative age-related macular degeneration: a preliminary report. European journal of ophthalmology. 2006; 16 (1):105-110. [PubMed: 16496253]

Pacher P, Beckman JS, Liaudet L. Nitric oxide and peroxynitrite in health and disease. Physiological reviews. 2007; 87 (1):315-424. [PubMed: 17237348]

Paravicini TM, Touyz RM. NADPH oxidases, reactive oxygen species, and hypertension: clinical implications and therapeutic possibilities. Diabetes Care. 2008; 31(Suppl 2):S170-180. [PubMed: 18227481]

Patel M, Day BJ, Crapo JD, Fridovich I, McNamara JO. Requirement for superoxide in excitotoxic cell death. Neuron. 1996; 16 (2):345-355. [PubMed: 8789949]

Pawlak A, Wrona M, Rozanowska M, Zareba M, Lamb LE, Roberts JE, Simon JD, Sarna T. Comparison of the aerobic photoreactivity of A2E with its precursor retinal. Photochemistry and photobiology. 2003; 77 (3):253-258. [PubMed: 12685651]

Polidori MC, Mecocci P, Stahl W, Sies H. Cigarette smoking cessation increases plasma levels of several antioxidant micronutrients and improves resistance towards oxidative challenge. $\mathrm{Br} \mathrm{J}$ Nutr. 2003; 90 (1):147-150. [PubMed: 12844386]

Pryor WA. Biological effects of cigarette smoke, wood smoke, and the smoke from plastics: the use of electron spin resonance. Free radical biology \& medicine. 1992; 13 (6):659-676. [PubMed: 1334034]

Reddy VN, Kasahara E, Hiraoka M, Lin LR, Ho YS. Effects of variation in superoxide dismutases (SOD) on oxidative stress and apoptosis in lens epithelium. Experimental eye research. 2004; 79 (6):859-868. [PubMed: 15642323]

Reinke LA. Spin trapping evidence for alcohol-associated oxidative stress. Free radical biology \& medicine. 2002; 32 (10):953-957. [PubMed: 12008110]

Romano AD, Serviddio G, de Matthaeis A, Bellanti F, Vendemiale G. Oxidative stress and aging. J Nephrol. 2010; 23(Suppl 15):S29-36. [PubMed: 20872368] 
Rozanowska M, Jarvis-Evans J, Korytowski W, Boulton ME, Burke JM, Sarna T. Blue light-induced reactivity of retinal age pigment. In vitro generation of oxygen-reactive species. The Journal of biological chemistry. 1995; 270 (32):18825-18830. [PubMed: 7642534]

Rozanowska M, Korytowski W, Rozanowski B, Skumatz C, Boulton ME, Burke JM, Sarna T. Photoreactivity of aged human RPE melanosomes: a comparison with lipofuscin. Invest Ophthalmol Vis Sci. 2002; 43 (7):2088-2096. [PubMed: 12091401]

Rozanowska M, Pawlak A, Rozanowski B, Skumatz C, Zareba M, Boulton ME, Burke JM, Sarna T, Simon JD. Age-related changes in the photoreactivity of retinal lipofuscin granules: role of chloroform-insoluble components. Invest Ophthalmol Vis Sci. 2004; 45 (4):1052-1060. [PubMed: 15037568]

Rozanowska M, Sarna T. Light-induced damage to the retina: role of rhodopsin chromophore revisited. Photochemistry and photobiology. 2005; 81 (6):1305-1330. [PubMed: 16120006]

Rozanowska M, Wessels J, Boulton M, Burke JM, Rodgers MA, Truscott TG, Sarna T. Blue lightinduced singlet oxygen generation by retinal lipofuscin in non-polar media. Free radical biology \& medicine. 1998; 24 (7-8):1107-1112. [PubMed: 9626564]

Rozanowski B, Cuenco J, Davies S, Shamsi FA, Zadlo A, Dayhaw-Barker P, Rozanowska M, Sarna T, Boulton ME. The phototoxicity of aged human retinal melanosomes. Photochemistry and photobiology. 2008; 84 (3):650-657. [PubMed: 18086241]

Rubinsztein DC, Marino G, Kroemer G. Autophagy and aging. Cell. 2011; 146 (5):682-695. [PubMed: 21884931]

Sanz A, Stefanatos RK. The mitochondrial free radical theory of aging: a critical view. Current aging science. 2008; 1 (1):10-21. [PubMed: 20021368]

Sarkar S, Davies JE, Huang Z, Tunnacliffe A, Rubinsztein DC. Trehalose, a novel mTOR-independent autophagy enhancer, accelerates the clearance of mutant huntingtin and alpha-synuclein. The Journal of biological chemistry. 2007; 282 (8):5641-5652. [PubMed: 17182613]

Sarkar S, Rubinsztein DC. Inositol and IP3 levels regulate autophagy: biology and therapeutic speculations. Autophagy. 2006; 2 (2):132-134. [PubMed: 16874097]

Sarkar S, Rubinsztein DC. Small molecule enhancers of autophagy for neurodegenerative diseases. Mol Biosyst. 2008; 4 (9):895-901. [PubMed: 18704227]

Sarna T. Properties and function of the ocular melanin--a photobiophysical view. J Photochem Photobiol B. 1992; 12 (3):215-258. [PubMed: 1635010]

Sastre J, Pallardo FV, Vina J. Mitochondrial oxidative stress plays a key role in aging and apoptosis. IUBMB life. 2000; 49 (5):427-435. [PubMed: 10902575]

Schafer FQ, Buettner GR. Redox environment of the cell as viewed through the redox state of the glutathione disulfide/glutathione couple. Free radical biology \& medicine. 2001; 30 (11):11911212. [PubMed: 11368918]

Schon EA, Dimauro S, Hirano M, Gilkerson RW. Therapeutic prospects for mitochondrial disease. Trends Mol Med. 2010

Seddon JM, Ajani UA, Mitchell BD. Familial aggregation of age-related maculopathy. American journal of ophthalmology. 1997; 123 (2):199-206. [PubMed: 9186125]

Seddon JM, George S, Rosner B. Cigarette smoking, fish consumption, omega-3 fatty acid intake, and associations with age-related macular degeneration: the US Twin Study of Age-Related Macular Degeneration. Arch Ophthalmol. 2006; 124 (7):995-1001. [PubMed: 16832023]

Segal AW, Abo A. The biochemical basis of the NADPH oxidase of phagocytes. Trends in biochemical sciences. 1993; 18 (2):43-47. [PubMed: 8488557]

Sengupta N, Caballero S, Sullivan SM, Chang LJ, Afzal A, Li Calzi S, Kielczewski JL, Prabarakan S, Ellis EA, Moldovan L, Moldovan NI, Boulton ME, Grant MB, Scott EW, Harris JR. Regulation of adult hematopoietic stem cells fate for enhanced tissue-specific repair. Molecular therapy : the journal of the American Society of Gene Therapy. 2009; 17 (9):1594-1604. [PubMed: 19584817]

Shacka JJ, Roth KA, Zhang J. The autophagy-lysosomal degradation pathway: role in neurodegenerative disease and therapy. Front Biosci. 2008; 13:718-736. [PubMed: 17981582]

Shamsi FA, Boulton M. Inhibition of RPE lysosomal and antioxidant activity by the age pigment lipofuscin. Invest Ophthalmol Vis Sci. 2001; 42 (12):3041-3046. [PubMed: 11687553] 
Shen J, Yang X, Xie B, Chen Y, Swaim M, Hackett SF, Campochiaro PA. MicroRNAs regulate ocular neovascularization. Molecular therapy : the journal of the American Society of Gene Therapy. 2008; 16 (7):1208-1216. [PubMed: 18500251]

Sohal RS, Orr WC. The redox stress hypothesis of aging. Free radical biology \& medicine. 2011

Sparrow JR, Boulton M. RPE lipofuscin and its role in retinal pathobiology. Experimental eye research. 2005; 80 (5):595-606. [PubMed: 15862166]

Spencer WA, Vadhanam MV, Jeyabalan J, Gupta RC. Oxidative DNA damage following microsome/ $\mathrm{Cu}$ (II)-mediated activation of the estrogens, 17beta-estradiol, equilenin and equilin: Role of reactive oxygen species. Chemical research in toxicology. 2011

Stadtman ER. Protein oxidation and aging. Free radical research. 2006; 40 (12):1250-1258. [PubMed: 17090414]

Stadtman ER, Levine RL. Protein oxidation. Annals of the New York Academy of Sciences. 2000; 899:191-208. [PubMed: 10863540]

Stahl W, Sies H. Bioactivity and protective effects of natural carotenoids. Biochimica et biophysica acta. 2005; 1740 (2):101-107. [PubMed: 15949675]

Sugiura H, Ichinose M. Nitrative stress in inflammatory lung diseases. Nitric oxide : biology and chemistry / official journal of the Nitric Oxide Society. 2011; 25 (2):138-144. [PubMed: 21440655]

Sun GY, Horrocks LA, Farooqui AA. The roles of NADPH oxidase and phospholipases A2 in oxidative and inflammatory responses in neurodegenerative diseases. Journal of neurochemistry. 2007; 103 (1):1-16. [PubMed: 17561938]

Sun GY, Shelat PB, Jensen MB, He Y, Sun AY, Simonyi A. Phospholipases A2 and inflammatory responses in the central nervous system. Neuromolecular medicine. 2010; 12 (2):133-148. [PubMed: 19855947]

Swaroop A, Chew EY, Rickman CB, Abecasis GR. Unraveling a multifactorial late-onset disease: from genetic susceptibility to disease mechanisms for age-related macular degeneration. Annu Rev Genomics Hum Genet. 2009; 10:19-43. [PubMed: 19405847]

Szaflik JP, Janik-Papis K, Synowiec E, Ksiazek D, Zaras M, Wozniak K, Szaflik J, Blasiak J. DNA damage and repair in age-related macular degeneration. Mutation research. 2009; 669 (1-2):169176. [PubMed: 19559717]

Szweda PA, Camouse M, Lundberg KC, Oberley TD, Szweda LI. Aging, lipofuscin formation, and free radical-mediated inhibition of cellular proteolytic systems. Ageing Res Rev. 2003; 2 (4): 383-405. [PubMed: 14522242]

Tanito M, Li F, Anderson RE. Protection of retinal pigment epithelium by OT-551 and its metabolite TEMPOL-H against light-induced damage in rats. Experimental eye research. 2010; 91 (1):111114. [PubMed: 20434439]

Tawfik A, Sanders T, Kahook K, Akeel S, Elmarakby A, Al-Shabrawey M. Suppression of retinal peroxisome proliferator-activated receptor gamma in experimental diabetes and oxygen-induced retinopathy: role of NADPH oxidase. Invest Ophthalmol Vis Sci. 2009; 50 (2):878-884. [PubMed: 18806296]

Taylor A, Lipman RD, Jahngen-Hodge J, Palmer V, Smith D, Padhye N, Dallal GE, Cyr DE, Laxman E, Shepard D, et al. Dietary calorie restriction in the Emory mouse: effects on lifespan, eye lens cataract prevalence and progression, levels of ascorbate, glutathione, glucose, and glycohemoglobin, tail collagen breaktime, DNA and RNA oxidation, skin integrity, fecundity, and cancer. Mechanisms of ageing and development. 1995; 79 (1):33-57. [PubMed: 7540704]

Thornton J, Edwards R, Mitchell P, Harrison RA, Buchan I, Kelly SP. Smoking and age-related macular degeneration: a review of association. Eye (Lond). 2005; 19 (9):935-944. [PubMed: 16151432]

Ting AY, Lee TK, MacDonald IM. Genetics of age-related macular degeneration. Curr Opin Ophthalmol. 2009; 20 (5):369-376. [PubMed: 19587596]

Traber MG, Winklhofer-Roob BM, Roob JM, Khoschsorur G, Aigner R, Cross C, Ramakrishnan R, Brigelius-Flohe R. Vitamin E kinetics in smokers and nonsmokers. Free radical biology \& medicine. 2001; 31 (11):1368-1374. [PubMed: 11728808] 
Tsimikas S. In vivo markers of oxidative stress and therapeutic interventions. The American journal of cardiology. 2008; 101 (10A):34D-42D.

Tsukamoto H, Lu SC. Current concepts in the pathogenesis of alcoholic liver injury. The FASEB journal : official publication of the Federation of American Societies for Experimental Biology. 2001; 15 (8):1335-1349.

Uchiki T, Weikel KA, Jiao W, Shang F, Caceres A, Pawlak D, Handa JT, Brownlee M, Nagaraj R, Taylor A. Glycation-altered proteolysis as a pathobiologic mechanism that links dietary glycemic index, aging, and age-related disease (in nondiabetics). Aging cell. 2012; 11 (1):1-13. [PubMed: 21967227]

Ushio-Fukai M, Alexander RW. Reactive oxygen species as mediators of angiogenesis signaling: role of NAD(P)H oxidase. Mol Cell Biochem. 2004; 264 (1-2):85-97. [PubMed: 15544038]

Vingerling JR, Hofman A, Grobbee DE, de Jong PT. Age-related macular degeneration and smoking. The Rotterdam Study. Arch Ophthalmol. 1996; 114 (10):1193-1196. [PubMed: 8859077]

Voloboueva LA, Killilea DW, Atamna H, Ames BN. N-tert-butyl hydroxylamine, a mitochondrial antioxidant, protects human retinal pigment epithelial cells from iron overload: relevance to macular degeneration. The FASEB journal : official publication of the Federation of American Societies for Experimental Biology. 2007; 21 (14):4077-4086.

Voulgaridou GP, Anestopoulos I, Franco R, Panayiotidis MI, Pappa A. DNA damage induced by endogenous aldehydes: current state of knowledge. Mutation research. 2011; 711 (1-2):13-27. [PubMed: 21419140]

Vugler A, Lawrence J, Walsh J, Carr A, Gias C, Semo M, Ahmado A, da Cruz L, Andrews P, Coffey P. Embryonic stem cells and retinal repair. Mech Dev. 2007; 124 (11-12):807-829. [PubMed: 17881192]

Waldeck AR, Stocker R. Radical-initiated lipid peroxidation in low density lipoproteins: insights obtained from kinetic modeling. Chemical research in toxicology. 1996; 9 (6):954-964. [PubMed: 8870982]

Wallace DC. Mitochondria, bioenergetics, and the epigenome in eukaryotic and human evolution. Cold Spring Harbor symposia on quantitative biology. 2009; 74:383-393.

Wallace DC. Mitochondrial DNA mutations in disease and aging. Environmental and molecular mutagenesis. 2010; 51 (5):440-450. [PubMed: 20544884]

Wang AL, Lukas TJ, Yuan M, Neufeld AH. Increased mitochondrial DNA damage and downregulation of DNA repair enzymes in aged rodent retinal pigment epithelium and choroid. Molecular vision. 2008; 14:644-651. [PubMed: 18392142]

Wardman P, Candeias LP. Fenton chemistry: an introduction. Radiation research. 1996; 145 (5):523531. [PubMed: 8619017]

Weissig V, Boddapati SV, Jabr L, D’Souza GG. Mitochondria-specific nanotechnology. Nanomedicine (London, England). 2007; 2 (3):275-285.

Wenz T, Diaz F, Spiegelman BM, Moraes CT. Activation of the PPAR/PGC-1alpha pathway prevents a bioenergetic deficit and effectively improves a mitochondrial myopathy phenotype. Cell metabolism. 2008; 8 (3):249-256. [PubMed: 18762025]

Winkler BS, Boulton ME, Gottsch JD, Sternberg P. Oxidative damage and age-related macular degeneration. Molecular vision. 1999; 5:32. [PubMed: 10562656]

Winslow AR, Rubinsztein DC. Autophagy in neurodegeneration and development. Biochimica et biophysica acta. 2008

Wong WT, Kam W, Cunningham D, Harrington M, Hammel K, Meyerle CB, Cukras C, Chew EY, Sadda SR, Ferris FL. Treatment of geographic atrophy by the topical administration of OT-551: results of a phase II clinical trial. Invest Ophthalmol Vis Sci. 2010; 51 (12):6131-6139. [PubMed: 20574018]

Xu SC, He MD, Lu YH, Li L, Zhong M, Zhang YW, Wang Y, Yu ZP, Zhou Z. Nickel exposure induces oxidative damage to mitochondrial DNA in Neuro2a cells: the neuroprotective roles of melatonin. Journal of pineal research. 2011; 51 (4):426-433. [PubMed: 21797922]

Yakes FM, Van Houten B. Mitochondrial DNA damage is more extensive and persists longer than nuclear DNA damage in human cells following oxidative stress. Proceedings of the National 
Academy of Sciences of the United States of America. 1997; 94 (2):514-519. [PubMed: 9012815]

Yang D, Elner SG, Bian ZM, Till GO, Petty HR, Elner VM. Pro-inflammatory cytokines increase reactive oxygen species through mitochondria and NADPH oxidase in cultured RPE cells. Experimental eye research. 2007; 85 (4):462-472. [PubMed: 17765224]

Yang JL, Weissman L, Bohr VA, Mattson MP. Mitochondrial DNA damage and repair in neurodegenerative disorders. DNA repair. 2008; 7 (7):1110-1120. [PubMed: 18463003]

Yatsuga S, Suomalainen A. Effect of bezafibrate treatment on late-onset mitochondrial myopathy in mice. Human molecular genetics. 2012; 21 (3):526-535. [PubMed: 22012983]

Yu DY, Cringle SJ. Retinal degeneration and local oxygen metabolism. Experimental eye research. 2005; 80 (6):745-751. [PubMed: 15939030]

Zarbin MA. Current concepts in the pathogenesis of age-related macular degeneration. Arch Ophthalmol. 2004; 122 (4):598-614. [PubMed: 15078679]

Zhao Z, Chen Y, Wang J, Sternberg P, Freeman ML, Grossniklaus HE, Cai J. Age-related retinopathy in NRF2-deficient mice. PloS one. 2011; 6 (4):e19456. [PubMed: 21559389]

Zhou Q, Gallagher R, Ufret-Vincenty R, Li X, Olson EN, Wang S. Regulation of angiogenesis and choroidal neovascularization by members of microRNA-23 27 24 clusters. Proceedings of the National Academy of Sciences of the United States of America. 2011; 108 (20):8287-8292.

[PubMed: 21536891] 


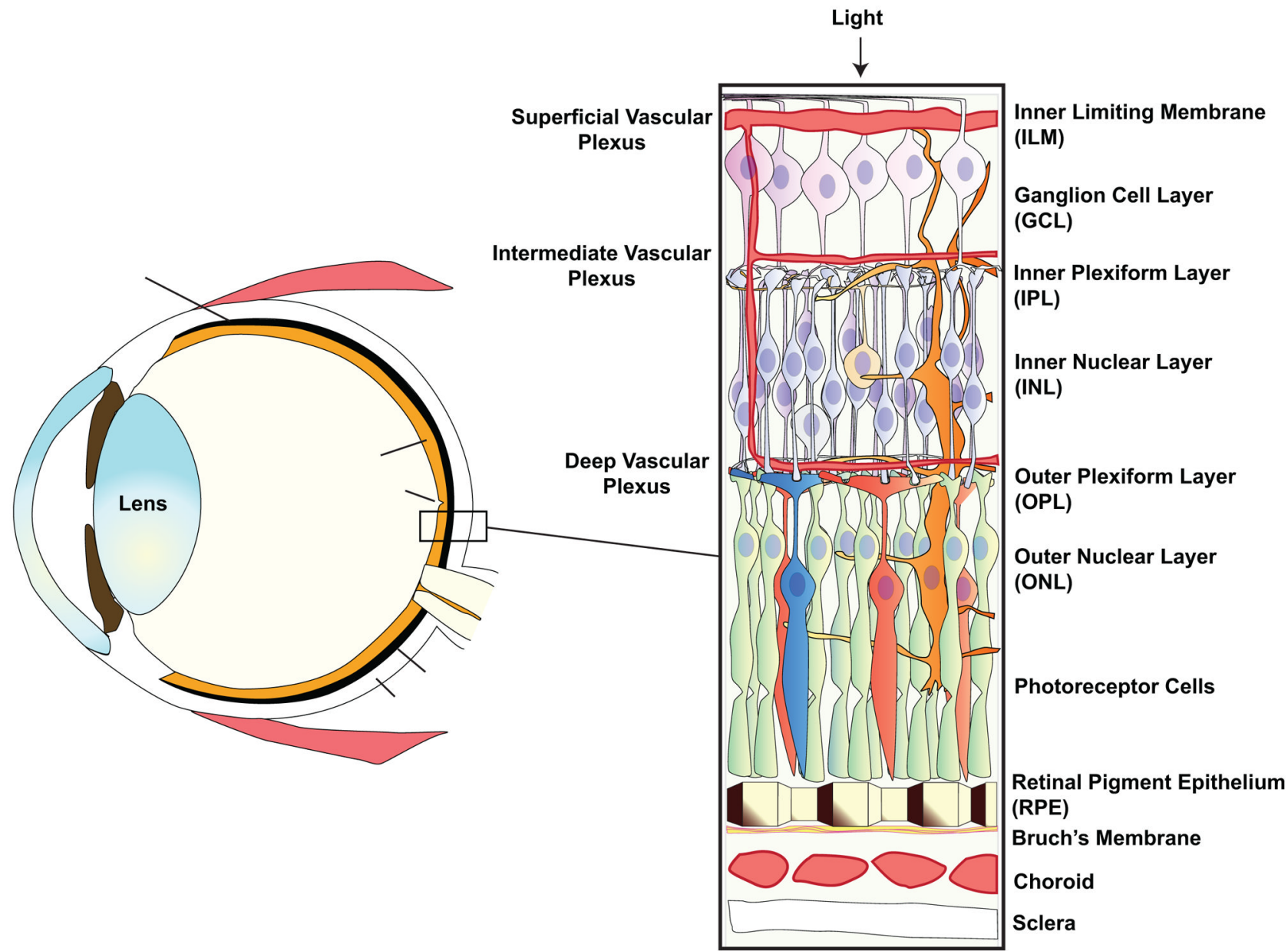

Figure 1.

A diagram of a cross section of the eye showing major structures. An enlarged diagram of the neural retina, underlying RPE, choroid and sclera is shown on the right. 


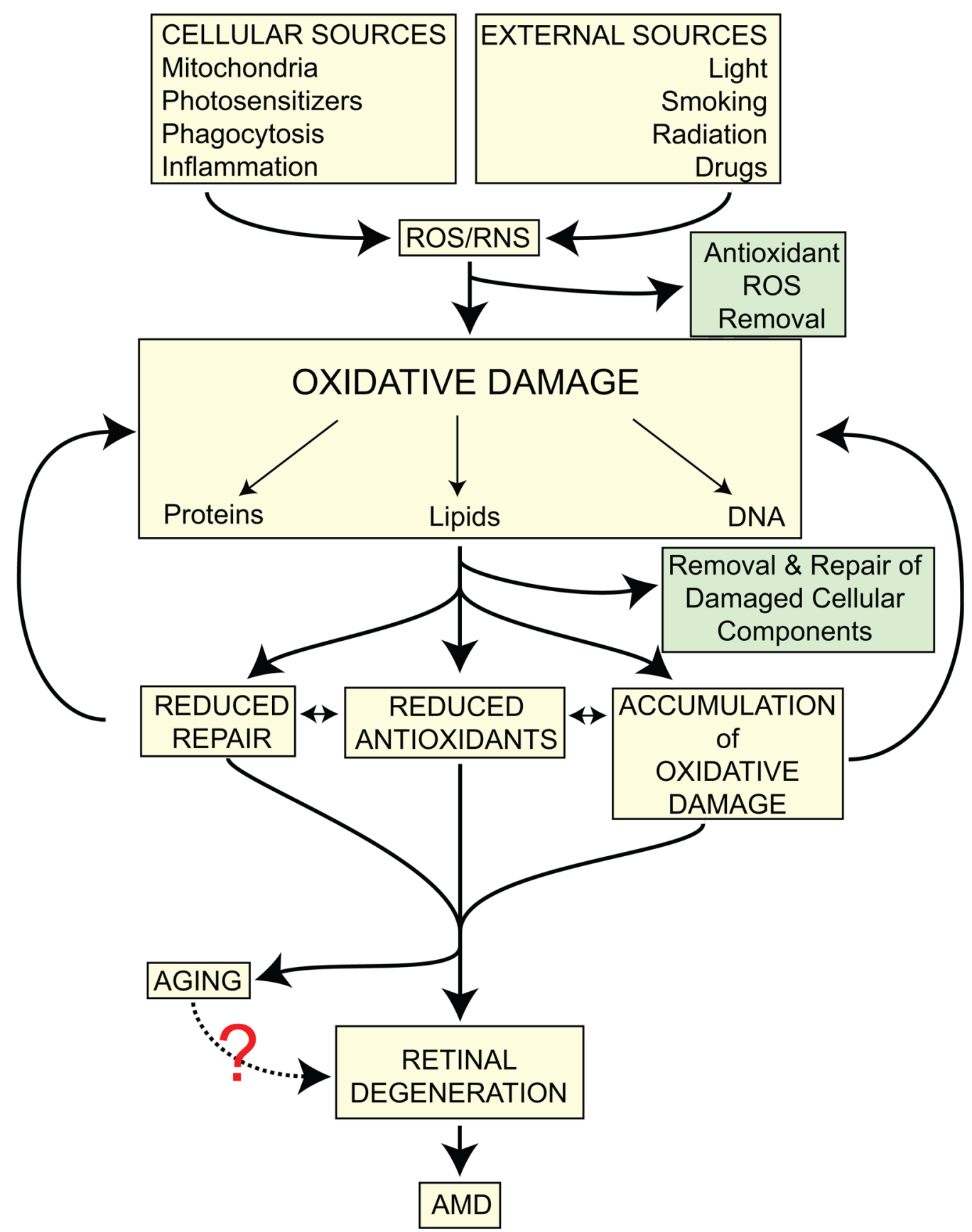

Figure 2.

A diagram depicting the potential pathways leading from oxidative stress to retinal degeneration and AMD. 
Table 1

Sources ROS in the retina

\begin{tabular}{ll}
\hline ROS & Common sources of retinal ROS \\
\hline $\mathrm{O}_{2}^{--}$ & Electron transport chain leakage, xanthine oxidase, flavoenzymes and arachidonic acid metabolism \\
$\mathrm{H}_{2} \mathrm{O}_{2}$ & Dismutation via SOD1/SOD2 and NADPH oxidase \\
$\mathrm{OH}^{-}$ & Fenton reactions \\
${ }^{1} \mathrm{O}_{2}$ & Photosensitization e.g. lipofuscin and aged melanin \\
$\mathrm{NO}^{-}$ & Nitric oxide synthesis \\
$\mathrm{OONO}^{-}$ & Reaction between NO with $\mathrm{O}_{2}^{-{ }^{-}}$ \\
LOO $/ \mathrm{LO}$ & Lipid peroxidation and phagocytosis \\
\hline
\end{tabular}

